\title{
Interferon Gamma Secretion of Adaptive and Innate Immune Cells as a Parameter to Describe Leukaemia-Derived Dendritic-Cell-Mediated Immune Responses in Acute Myeloid Leukaemia in vitro
}

\author{
Lara Kristina Klauer $^{\mathrm{a}}$ Olga Schutti ${ }^{\mathrm{a}}$ Selda Ugur ${ }^{\mathrm{a}}$ Fatemeh Doraneh-Gard ${ }^{\mathrm{a}}$ \\ Daniel Christoph Amberger ${ }^{\mathrm{a}} \quad$ Nicole Rogers $^{\mathrm{a}}$ Doris Krämer ${ }^{\mathrm{b}}$ Andreas Rank $^{\mathrm{c}}$ \\ Christoph Schmid $^{c}$ Britta Eiz-Vesper ${ }^{d}$ Helga Maria Schmetzer ${ }^{a}$

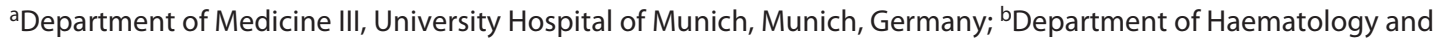 \\ Oncology, St.-Josefs-Hospital, Hagen, Germany; ' Department of Haematology and Oncology, University Hospital of \\ Augsburg, Augsburg, Germany; Institute for Transfusion Medicine, Hannover Medical School, Hannover, Germany
}

\begin{abstract}
Keywords
Leukaemia-derived dendritic cells · Acute myeloid leukaemia - Anti-leukaemic functionality ·

Leukaemia-specific cells · Cytokine secretion assay
\end{abstract}

\begin{abstract}
Introduction: Myeloid leukaemic blasts can be converted into leukaemia-derived dendritic cells $\left(\mathrm{DC}_{\mathrm{leu}}\right)$, characterised by the simultaneous expression of dendritic- and leukaemiaassociated antigens, which have the competence to prime and enhance (leukaemia-specific) immune responses with the whole leukaemic antigen repertoire. To display and further specify dendritic cell (DC)- and $D C_{\text {leu-mediated immune }}$ responses, we analysed the interferon gamma (IFNy) secretion of innate and adaptive immune cells. Methods: DC/ $\mathrm{DC}_{\text {leu }}$ were generated from leukaemic whole blood (WB) with (blast)modulatory Kit-I (granulocyte-macrophage colony-stimulating factor [GM-CSF] + Picibanil [OK-432]) and Kit$\mathrm{M}$ (GM-CSF + prostaglandin E1) and were used to stimulate T cell-enriched immunoreactive cells. Initiated anti-leukaemic cytotoxicity was investigated with a cytotoxicity fluorolysis assay. Initiated IFNy secretion of T, NK, CIK, and iNKT cells was investigated with a cytokine secretion assay (CSA). IFNy positivity was additionally evaluated with an intracellular cytokine assay (ICA). Recent activation of leukaemia-specific
\end{abstract}

cells was verified through addition of leukaemia-associated antigens (LAA; WT-1 and Prame) Results: We found Kit-I and Kit-M competent to generate mature $D C$ and $D C_{\text {leu }}$ from leukaemic WB without induction of blast proliferation. Stimulation of immunoreactive cells with $\mathrm{DC} / \mathrm{DC} C_{\text {leu }}$ regularly resulted in an increased anti-leukaemic cytotoxicity and increased IFNy secretion of T, NK, and CIK cells, pointing to the significant role of $\mathrm{DC} / D C_{\text {leu }}$ in leukaemia-specific alongside antileukaemic reactions. Interestingly, an addition of LAA did not further increase IFNy secretion, suggesting an efficient activation of leukaemia-specific cells. Here, both the CSA and ICA yielded comparable frequencies of IFNy-positive cells. Remarkably, the anti-leukaemic cytotoxicity positively correlated with the IFNy secretion in $\mathrm{T}^{\mathrm{CD} 3+}, \mathrm{T}^{\mathrm{CD} 4+}, \mathrm{T}^{\mathrm{CD} 8+}$, and $\mathrm{NK}^{\mathrm{CD} 56+}$ cells. Conclusion: Ultimately, the IFNy secretion of innate and adaptive immune cells appeared to be a suitable parameter to assess and monitor the efficacy of in vitro and potentially in vivo acute myeloid leukaemia immunotherapy. The CSA in this regard proved to be a convenient and reproducible technique to detect and phenotypically characterise IFNy-secreting cells. In respect to our studies on DCbased immunomodulation, we were able to display the potential of $\mathrm{DC} / \mathrm{DC} C_{\text {leu }}$ to induce or improve leukaemia-specific and anti-leukaemic activity.

(C) 2021 The Author(s)

Published by S. Karger AG, Basel

\section{karger@karger.com} www.karger.com/tmh

Karger $\frac{1}{\%}$

BOPEN ACCESS
(C) 2021 The Author(s)

Published by S. Karger AG, Basel

This is an Open Access article licensed under the Creative Common Attribution-NonCommercial-4.0 International License (CC BY-NC) (http://www.karger.com/Services/OpenAccessLicense), applicable to the online version of the article only. Usage and distribution for commercial purposes requires written permission.
Correspondence to:

Helga Maria Schmetzer, helga.schmetzer@med.uni-muenchen.de 


\section{Introduction}

Acute myeloid leukaemia (AML) is a malignant disorder of haematopoietic stem cells characterised by the uncontrolled clonal expansion of abnormally differentiated myeloid blasts. Displacing the physiological haematopoiesis, the accumulation of leukaemic blasts causes typical complications such as erythrocytopenia, thrombocytopenia, and leukocytopenia $[1,2]$. Standard therapy for AML consists of chemotherapy with or without allogeneic haematopoietic stem cell transplantation $[3,4]$. With overall 5 -year survival rates of $28.7 \%$, mainly due to infections and relapses initiated by leukaemic stem cells and residual blasts, the outcome though remains unsatisfactory [5-7].

In recent years, immunotherapeutic approaches in the treatment of AML have gained attention. Different strategies have been developed with the attempt to redirect the immune system in order to overcome the leukaemic immune escape and enforce a tumour-specific immune response. One of the most auspicious approaches in this regard involves the use of dendritic cell (DC)-based vaccines [8-11]. DCs are some of the most potent antigenpresenting cells of the immune system. As they link the innate and the adaptive immune system, they are pivotal in initiating and regulating an antigen-specific immune response $[12,13]$. As such, DCs can be exploited to present tumour antigens in order to induce a potent anti-tumour immunity.

DCs can be generated ex vivo from leukaemic myeloid blasts resulting in mature leukaemia-derived $\mathrm{DC}\left(\mathrm{DC}_{\text {leu }}\right)$ [14-16], characterised by the simultaneous expression of dendritic cell antigens, leukaemia-specific antigens, and CCR7 as maturation and migration marker [17, 18]. Thus, presenting the whole leukaemic antigen repertoire, mature $\mathrm{DC}_{\text {leu }}$ have the competence to activate $\mathrm{T}$ cells and likely natural killer cells (NK cells), cytokine-induced killer cells (CIK cells), and invariant natural killer cells (iNKT) to (re)gain leukaemia-specific activity $[15,16$, 18-20].

Leukaemia-specific activity or rather cytotoxicity implies a complex synergy of the innate and adaptive cellular immune system as well as the humoral immune system. Cytotoxicity is exerted by various innate and adaptive immune cells via different mechanisms: through the (rather early and fast) release of the cytolytic molecules perforin and granzyme by degranulation, through the (rather late and slow) interaction with the Fas ligand (FasL) and TNF-related apoptosis-including ligand (TRAIL), and/or through the secretion of tumour necrosis factor alpha (TNFa) and interferon gamma (IFNy) [21-23]. Especially the latter, IFNy, has a wide-ranging role: it is not only essential to regular immunity, promoting innate and adaptive immune responses and thereby licensing im- mune cells to exert cytotoxicity, but also strongly associated with anti-tumour immunity, promoting tumour surveillance, recognition, and elimination [24]. However, it has been noted before that under certain circumstances IFNy can also stimulate immune-suppressive mechanisms in tumour cells, including upregulation of indoleamine 2,3-dioxygenase and of checkpoint inhibitors such as programmed cell-death ligand 1, leading to immune escape $[25,26]$.

In the early phase of an immune response, IFNy is mainly secreted by innate immune cells such as NK, iNKT, DC, and macrophages upon activation $[27,28]$. It not only stimulates innate immune cells by enhancing their effector mechanisms and IFNy secretion, but also facilitates tumour recognition and elimination. By upregulation of the major histocompatibility complex (MHC) class I and II antigen- and cross-presentation pathways, as well as the MHC-II expression on classically non-MHC-II-expressing cells, it increases the perceptibility of tumour cells to adaptive immune cells. Moreover, by up-regulation of the expression of FasR, FasL, TRAIL, caspase- $1,-3,-7,-8$, and BIM and downregulating the expression of survivin, it increases the susceptibility of tumour cells to extrinsic and intrinsic pathways of apoptosis [25, 26, 29-33]. Importantly, by promoting the differentiation, proliferation, and activation of helper T cells type 1 (Th1) and cytotoxic T cells (Tc), IFNy links the innate and adaptive immunity, thereby commencing the advanced phase of an immune response. Moreover, it inhibits the differentiation of helper T cells type 2 (Th2) and regulatory T cells [26-28, 34]. In the advanced phase of an immune response, IFNy is mainly secreted by adaptive immune cells such as Th1 and Tc cells upon primary activation by DC or secondary activation by its specific antigen. IFNy thereupon not only stimulates adaptive immune cells by enhancing their effector mechanisms and IFNy secretion, but also innate immune cells $[27,28,35]$. That way, IFNy creates a positive feedback loop and, together with further cytokines, is able to stimulate and sustain an effective immune response, incorporating both innate and adaptive immune cells.

IFNy is considered as sine qua non for the immune system. It is an important mediator of the innate and adaptive immunity and plays a pivotal role in anti-tumour immunity. A blockade of this critical cytokine restrains an effective immune defence [36,37]. This inseparable connection between IFNy and cell-based immunity has lead us to hypothesise that IFNy could be a suitable parameter to display leukaemia-specific activity and cytotoxicity. Particularly in respect to future applications, IFNy readouts might have the potential to be a convenient parameter to assess and monitor the efficacy of AML immunotherapy. 
Table 1. Patients' characteristics

\begin{tabular}{|c|c|c|c|c|c|c|c|c|c|}
\hline $\begin{array}{l}\text { Patient } \\
\text { No. }\end{array}$ & Age & Sex & $\begin{array}{l}\text { FAB } \\
\text { type }\end{array}$ & Stage & Blast phenotype $(\mathrm{CD})$ & $\begin{array}{l}\text { IC } \\
\text { blasts, } \%\end{array}$ & Cyto-, molecular genetics & Source & Conducted experiments \\
\hline \multicolumn{10}{|l|}{ AML } \\
\hline 1489 & 55 & f & $\mathrm{p}-\mathrm{M} 0$ & dgn & $13,33, \mathbf{3 4}, 65,117$ & 61 & 46, XX; FLT3-ITD mut, NMP1 mut & MNC & DCC, MLC, CTX, CSA \\
\hline 1490 & 65 & $\mathrm{~m}$ & $\mathrm{~s}-\mathrm{M} ?$ & dgn & $15,33,56,65$ & 46 & 46, XY; del(20) (q12q13)[12]; NPM1 wt & MNC & DCC, MLC, CTX, CSA \\
\hline 1509 & 60 & $\mathrm{~m}$ & $\mathrm{p}-\mathrm{M} 2$ & dgn & $13,33, \mathbf{3 4}, 65,117$ & 48 & 46, XY; FLT3-TKD wt, NPM1 mut & $\mathrm{WB}$ & DCC, MLC, CTX, CSA, ICA \\
\hline 1511 & 78 & $\mathrm{~m}$ & $\mathrm{p}-\mathrm{M} 4$ & rel & $13,15,33, \mathbf{3 4}, 65,117$ & 54 & FLT3-ITD mut, RUNX1 mut & WB & DCC, MLC, CTX, CSA \\
\hline 1514 & 68 & $\mathrm{~m}$ & $\mathrm{~s}-\mathrm{M}$ ? & dgn & $33,56,117$ & 36 & 46, XY; FLT3-TKD wt, NPM1 mut & WB & DCC, MLC, CSA \\
\hline 1515 & 67 & $\mathrm{f}$ & $\mathrm{p}-\mathrm{M} 2$ & dgn & $33, \mathbf{3 4}, 65,117$ & 80 & 46, XX; FLT3-TKD wt, NPM1 mut & WB & DCC, MLC, CSA \\
\hline 1518 & 83 & $\mathrm{f}$ & $\mathrm{p}-\mathrm{M} 5$ & dgn & $14,15,34,65$ & 72 & 46, XX; FLT3-TKD wt, NPM1 mut & WB & DCC, MLC, CSA, ICA \\
\hline 1521 & 56 & $\mathrm{~m}$ & $\mathrm{p}-\mathrm{M} 4$ & dgn & $13,15,33,34,65,117$ & 72 & 46, XY; FLT3-TKD mut, NPM1 mut & WB & DCC, MLC, CTX, CSA \\
\hline 1525 & 77 & $\mathrm{~m}$ & $\mathrm{p}-\mathrm{M} 1$ & dgn & $13,15,33, \mathbf{3 4}, 117$ & 78 & $\begin{array}{l}\text { 46, XY; FLT3-ITD wt, FLT3-TKD mut, } \\
\text { NPM1 mut }\end{array}$ & WB & DCC, MLC, CSA \\
\hline 1526 & 74 & f & $\mathrm{p}-\mathrm{M} ?$ & dgn & $15,33, \mathbf{3 4}, 56, \mathbf{6 5}, 117$ & 59 & 46, XX; FLT3-TKD wt, NPM1 mut & WB & DCC, MLC, CSA \\
\hline 1527 & 42 & $\mathrm{~m}$ & $\mathrm{p}-\mathrm{M} 2$ & dgn & $7,13,15,33, \mathbf{3 4}, \mathbf{6 5}, 117$ & 51 & 46, XY; FLT3-ITD mut, NPM1 mut & WB & DCC, MLC, CTX, CSA, ICA \\
\hline 1531 & 71 & $\mathrm{~m}$ & $\mathrm{p}-\mathrm{M} 4 / 5$ & dgn & $13,33,34,117$ & 24 & n.d. & WB & DCC, MLC, CSA, ICA \\
\hline 1536 & 61 & $\mathrm{~m}$ & $\mathrm{p}-\mathrm{M} 5$ & dgn & $14,34,56$ & 73 & 46, XY; NPM1 mut & WB & DCC, MLC, CTX, CSA \\
\hline 1562 & 37 & $\mathrm{~m}$ & $\mathrm{p}-\mathrm{M} 1$ & dgn & $2,7,13, \mathbf{3 4}, 117$ & 82 & $\begin{array}{l}\text { 46, XY; del(2) (q21), der(14) t }(2 ; 14) \\
\text { (q21; q32)[7]/46,XY[3]; FLT3-TKD mut, } \\
\text { RUNX1 mut }\end{array}$ & WB & DCC, MLC, CTX, CSA \\
\hline 1565 & 62 & $\mathrm{f}$ & $\mathrm{p}-\mathrm{M} 4$ & dgn & $13,15, \mathbf{3 4}, 65,117$ & 31 & $46, \mathrm{XX}$ & WB & DCC, MLC, CTX, CSA \\
\hline 1567 & 98 & $\mathrm{f}$ & $\mathrm{p}-\mathrm{M}$ ? & dgn & $14,15,34,56$ & 57 & $\begin{array}{l}46, \mathrm{XX} \operatorname{del}(5 \mathrm{q} 31), \operatorname{del}(5 \mathrm{q} 32-33), \mathrm{MECOM} \\
\text { rearrangement inv(3) (q21q26.2)/t( } 3 ; 3)\end{array}$ & WB & DCC, MLC, CTX, CSA \\
\hline 1568 & 29 & $\mathrm{~m}$ & $\mathrm{p}-\mathrm{M}$ ? & dgn & $10,13,33,34$ & 79 & $\begin{array}{l}\text { (q21;q26.2); FLT3-TKD wt, NPM1 wt } \\
46, \mathrm{XY}\end{array}$ & $\mathrm{WB}$ & DCC, MLC, CTX, CSA \\
\hline 1570 & 36 & $\mathrm{f}$ & $\mathrm{p}-\mathrm{M}$ ? & dgn & $7,13,14,33,34,117$ & 33 & $46, \mathrm{XX} ; \mathrm{NPM1}$ mut & WB & DCC, MLC, CTX, CSA \\
\hline 1572 & 64 & $\mathrm{f}$ & $\mathrm{p}-\mathrm{M}$ ? & dgn & $13,33,34,65,117$ & 50 & $\begin{array}{l}\text { 46, XX; RUNX1 mut, EZH2 mut, BCOR } \\
\text { mut, U2AF1 mut, ASXL1 mut }\end{array}$ & WB & DCC, MLC, CTX, CSA, ICA \\
\hline \multicolumn{10}{|l|}{ Healthy } \\
\hline 1486 & 57 & $\mathrm{f}$ & & & & & & MNC & CSA \\
\hline 1499 & 21 & $\mathrm{f}$ & & & & & & MNC, WB & DCC, MLC, CSA \\
\hline 1505 & 22 & $\mathrm{~m}$ & & & & & & MNC, WB & DCC, MLC, CSA \\
\hline 1523 & 17 & $\mathrm{~m}$ & & & & & & WB & DCC, MLC, CSA \\
\hline
\end{tabular}

The aim of the study was to generate $\mathrm{DC} / \mathrm{DC}_{\text {leu }}$ with immunomodulatory Kit-I and Kit-M (DC/DC $\mathrm{leu}^{-K i t-I}$ and $\mathrm{DC} / \mathrm{DC}_{\mathrm{leu}}-\mathrm{Kit}-\mathrm{M}$ ) from leukaemic whole blood (WB) and therewith stimulate autologous T cell-enriched immunoreactive cells. We investigated the resulting anti-leukaemic cytotoxicity with a cytotoxicity fluorolysis assay (CTX) and the resulting IFNy secretion of innate and adaptive immune cells with a cytokine secretion assay (CSA). IFNy production was additionally evaluated with an intracellular cytokine assay (ICA). Ultimately, we correlated the IFNy secretion with the antileukaemic cytotoxicity of $\mathrm{DC} / \mathrm{DC}_{\text {leu}}$-stimulated immunoreactive cells.

\section{Material and Methods}

\section{Sample Collection}

Sample collection was conducted after obtaining written informed consent of the blood donor and in accordance with the World Medical Association Declaration of Helsinki and the ethic committee of the Ludwig Maximilian University Hospital Munich (vote No. 33905). Samples in form of heparinised peripheral WB were provided by the University Hospitals of Augsburg, Oldenburg, and Munich.

\section{Patients' Characteristics}

Blood samples were obtained from AML patients $(n=19)$ with a mean age of 62.2 years (range 29-98 years) and a femaleto-male ratio of $1: 1.4$, and from healthy volunteers $(n=4)$ with a mean age of 29.3 (range 16-57 years) and a female-to-male ratio of 1:1. AML patients were characterised by the French-American-British (FAB) classification (M1-M7), the aetiology (primary $A M L$, secondary $A M L$ ), the stage of disease (first diagnosis, relapse), the blast phenotype, the blast frequency in peripheral blood, and the cyto- and molecular genetics. An overview is given in Table 1.

AML patients presented in $\mathrm{WB} /$ mononuclear cells (MNC) with an average of $57.6 / 53.6 \%$ leukemic blasts (range 23.780.4/45.9-61.2\%), 11.4/1.4\% $\mathrm{T}^{\mathrm{CD} 3+}$ cells (range 0.9-19.4/0.5$2.2 \%$ ), $3.3 / 7.6 \% \mathrm{~B}^{\mathrm{CD} 19+}$ cells (range $0.1-3.9 / 0.7-14.6 \%$ ), $2.8 / 0.7 \%$ $\mathrm{NK}^{\mathrm{CD} 56+}$ cells (range $0.3-8.1 / 0.5-0.9 \%$ ), and $5.3 / 2.7 \%$ monocytes ${ }^{\mathrm{CD} 14+}$ (range $0-16.3 / 1.6-3.7 \%$ ). In cases with aberrant expression of $\mathrm{T}, \mathrm{B}, \mathrm{NK}$, or monocytoid antigens, proportions were not included in the analyses.

Cell Characterisation by Flow Cytometry

Flow cytometric analyses were implemented to evaluate and quantify frequencies, phenotypes, and subsets of leukaemic blasts, 
Table 2. Cells and cell subsets as evaluated by flow cytometry

\begin{tabular}{|c|c|c|c|c|c|}
\hline & $\begin{array}{l}\text { Abbreviation } \\
\text { of subgroups }\end{array}$ & Surface marker & Referred to & Abbreviation & Ref. \\
\hline \multicolumn{6}{|l|}{ Blast cells } \\
\hline Blasts & BLA & $\begin{array}{l}\mathrm{BLA}^{+}\left(\mathrm{CD} 15^{+}, \mathrm{CD} 34^{+} \text {, }\right. \\
\left.\mathrm{CD} 5^{+}, \mathrm{CD} 117^{+}\right)\end{array}$ & WB or MNC & BLA/WB or/MNC & {$[17]$} \\
\hline Proliferating blasts & $\mathrm{BLA}_{\text {prol }}$ & $\mathrm{BLA}^{+} \mathrm{DC}^{-} \mathrm{CD}^{-} 1^{+}$ & BLA & $\mathrm{BLA}_{\mathrm{prol}} / \mathrm{BLA}$ & [39] \\
\hline \multicolumn{6}{|l|}{ Dendritic cells } \\
\hline Dendritic cells & DC & $\mathrm{DC}^{+}\left(\mathrm{CD} 80^{+}, \mathrm{CD} 206^{+}\right)$ & WB or MNC & $\mathrm{DC} / \mathrm{WB}$ & [17] \\
\hline Leukaemia-derived DC & $\mathrm{DC}_{\text {leu }}$ & $\mathrm{DC}^{+} \mathrm{BLA}^{+}$ & $\begin{array}{l}\text { WB or MNC } \\
\text { DC }\end{array}$ & $\begin{array}{l}\mathrm{DC}_{\mathrm{leu}} / \mathrm{WB} \text { or } / \mathrm{MNC} \\
\mathrm{DC}_{\mathrm{leu}} / \mathrm{DC}\end{array}$ & [17] \\
\hline Mature DC & $\mathrm{DC}_{\text {mat }}$ & $\mathrm{DC}^{+} \mathrm{CCR}^{+}$ & $\begin{array}{l}\text { BLA } \\
\text { WB or MNC } \\
\text { DC }\end{array}$ & $\begin{array}{l}\mathrm{DC}_{\text {leu }} / \mathrm{BLA} \\
\mathrm{DC}_{\text {mat }} / \mathrm{WB} \text { or } / \mathrm{MNC} \\
\mathrm{DC}_{\text {mat }} / \mathrm{DC}\end{array}$ & [18] \\
\hline Mature $\mathrm{DC}_{\mathrm{leu}}$ & $\mathrm{DC}_{\text {mat-leu }}$ & $\mathrm{DC}^{+} \mathrm{BLA}^{+} \mathrm{CCR} 7^{+}$ & $\begin{array}{l}\mathrm{WB} \text { or } \mathrm{MNC} \\
\mathrm{DC}_{\text {leu }} \\
\mathrm{DC}_{\text {mat }}\end{array}$ & $\begin{array}{l}\mathrm{DC}_{\text {leu-mat }} / \mathrm{WB} \text { or } / \mathrm{MNC} \\
\mathrm{DC}_{\text {leu-mat }} / \mathrm{DC}_{\text {leu }} \\
\mathrm{DC}_{\text {leu-mat }} / \mathrm{DC}_{\text {mat }}\end{array}$ & \\
\hline \multicolumn{6}{|l|}{ Monocytoid cells } \\
\hline $\mathrm{CD} 14^{+}$monocytes & monocytes ${ }^{\mathrm{CD} 14+}$ & $\mathrm{CD} 14^{+}$ & WB & monocytes $\mathrm{CD} 14+^{-} \mathrm{WB}$ & [18] \\
\hline \multicolumn{6}{|l|}{$T$ cells } \\
\hline $\mathrm{CD}^{+}$pan T cells & $\mathrm{T}^{\mathrm{CD} 3+}$ & $\mathrm{CD}^{+}$ & WB or MNC & $\mathrm{T}^{\mathrm{CD} 3+} / \mathrm{WB}$ or $\mathrm{MNC}$ & {$[75]$} \\
\hline $\mathrm{CD}^{+}{ }^{+}$-coexpressing $\mathrm{T}$ cells & $\mathrm{T}^{\mathrm{CD} 4+}$ & $\mathrm{CD}^{+} \mathrm{CD}^{+}$ & $\mathrm{CD}^{+}$ & $\mathrm{T}^{\mathrm{CD} 4+} / \mathrm{CD}^{+}$ & {$[75]$} \\
\hline $\mathrm{CD}^{+}{ }^{+}$coexpressing $\mathrm{T}$ cells & $\mathrm{T}^{\mathrm{CD} 8+}$ & $\mathrm{CD}^{+} \mathrm{CD}^{+}$ & $\mathrm{CD}^{+}$ & $\mathrm{T}^{\mathrm{CD} 8+} / \mathrm{CD}^{+}$ & [75] \\
\hline Naive T cells & $\mathrm{T}_{\text {naive }}$ & $\mathrm{CD}^{+}{ }^{+} \mathrm{CD} 45 \mathrm{RO}^{-}$ & $\mathrm{CD}^{+}$ & $\mathrm{T}_{\text {naive }} / \mathrm{CD}^{+}$ & [41] \\
\hline Non-naive T cells & $\mathrm{T}_{\text {non-naive }}$ & $\mathrm{CD}^{+} \mathrm{CD}^{2} 5 \mathrm{RO}^{+}$ & $\mathrm{CD}^{+}$ & $\mathrm{T}_{\text {non-naive }} / \mathrm{CD}^{+}$ & [41] \\
\hline Central (memory) T cells & $\mathrm{T}_{\mathrm{cm}}$ & $\mathrm{CD}^{+} \mathrm{CD}^{+} 5 \mathrm{RO}^{+} \mathrm{CCR}^{+}$ & $\mathrm{CD}^{+}$ & $\mathrm{T}_{\mathrm{cm}} / \mathrm{CD}^{+}$ & [41] \\
\hline Effector (memory) T cells & $\mathrm{T}_{\mathrm{em}}$ & $\mathrm{CD}^{+} \mathrm{CD}^{2} 5 \mathrm{RO}^{+} \mathrm{CCR}^{-}$ & $\mathrm{CD}^{+}$ & $\mathrm{T}_{\mathrm{em}} / \mathrm{CD}^{+}$ & [41] \\
\hline Proliferating T cells - early & $\mathrm{T}_{\text {prol-early }}$ & $\mathrm{CD}^{+} \mathrm{CD} 9^{+}$ & $\mathrm{CD}^{+}$ & $\mathrm{T}_{\text {prol-early }} / \mathrm{CD}^{+}$ & [75] \\
\hline Proliferating T cells - late & $\mathrm{T}_{\text {prol-late }}$ & $\mathrm{CD}^{+} \mathrm{CD} 1^{+}$ & $\mathrm{CD}^{+}$ & $\mathrm{T}_{\text {prol-late }} / \mathrm{CD}^{+}$ & [75] \\
\hline \multicolumn{6}{|l|}{ B cells } \\
\hline $\mathrm{CD} 19^{+} \mathrm{B}$ cells & $\mathrm{B}^{\mathrm{CD} 19+}$ & $\mathrm{CD}_{1} 9^{+}$ & WB or MNC & $\mathrm{B}^{\mathrm{CD} 19+} / \mathrm{WB}$ or $/ \mathrm{MNC}$ & {$[20]$} \\
\hline \multicolumn{6}{|l|}{ CIK cells } \\
\hline $\mathrm{CD}^{+}{ }^{+} \mathrm{CD} 56^{+} \mathrm{CIK}$ cells & $\mathrm{CIK}^{\mathrm{CD} 56+}$ & $\mathrm{CD}^{+} \mathrm{CD} 6^{+}$ & WB or MNC & $\mathrm{CIK}^{\mathrm{CD} 56+} / \mathrm{WB}$ or $/ \mathrm{MNC}$ & [20] \\
\hline $\mathrm{CD}^{+} \mathrm{CD} 161^{+} \mathrm{CIK}$ cells & $\mathrm{CIK}^{\mathrm{CD} 161+}$ & $\mathrm{CD}^{+}{ }^{+} \mathrm{CD} 161^{+}$ & WB or MNC & $\mathrm{CIK}^{\mathrm{CD} 161+} / \mathrm{WB}$ or $/ \mathrm{MNC}$ & \\
\hline \multicolumn{6}{|l|}{ NK cells } \\
\hline $\mathrm{CD}^{-}{ }^{-} \mathrm{CD} 56^{+} \mathrm{NK}$ cells & $\mathrm{NK}^{\mathrm{CD} 56+}$ & $\mathrm{CD}^{-} \mathrm{CD}^{-} 6^{+}$ & WB or MNC & $\mathrm{NK}^{\mathrm{CD} 56+} / \mathrm{WB}$ or $/ \mathrm{MNC}$ & {$[20]$} \\
\hline $\mathrm{CD}^{-}{ }^{-} \mathrm{CD} 161^{+} \mathrm{NK}$ cells & $\mathrm{NK}^{\mathrm{CD} 161+}$ & $\mathrm{CD}^{-}{ }^{-} \mathrm{CD} 161^{+}$ & WB or MNC & $\mathrm{NK}^{\mathrm{CD} 161+} / \mathrm{WB}$ or $/ \mathrm{MNC}$ & \\
\hline \multicolumn{6}{|l|}{ iNKT cells } \\
\hline $6 \mathrm{~B} 11^{+}$iNKT cells & iNKT & $6 \mathrm{~B} 11+$ & WB or MNC & $\mathrm{iNKT} / \mathrm{WB}$ or /MNC & [20] \\
\hline \multicolumn{6}{|l|}{ IFNy-secreting cells } \\
\hline IFNy-secreting $\mathrm{CD}^{+}$pan $\mathrm{T}$ cells & & $\mathrm{CD}^{+} \mathrm{IFNy}^{+}$ & $\mathrm{CD}^{+}$ & $\mathrm{T}^{\mathrm{CD} 3+} \mathrm{IFNy}^{+} / \mathrm{T}^{\mathrm{CD} 3+}$ & \\
\hline IFNy-secreting $\mathrm{CD} 4^{+}$-coexpressing $\mathrm{T}$ cells & & $\mathrm{CD}^{+} \mathrm{CD}^{+} \mathrm{IFNy}^{+}$ & $\mathrm{CD}^{+} \mathrm{CD}^{+}$ & $\mathrm{T}^{\mathrm{CD} 4+} \mathrm{IFNy}^{+} / \mathrm{T}^{\mathrm{CD} 4+}$ & \\
\hline IFNy-secreting $\mathrm{CD}^{+}{ }^{+}$-coexpressing $\mathrm{T}$ cells & & $\mathrm{CD}^{+} \mathrm{CD}^{+} \mathrm{IFNy}^{+}$ & $\mathrm{CD}^{+} \mathrm{CD}^{+}$ & $\mathrm{T}^{\mathrm{CD} 8+} \mathrm{IFNy}^{+} / \mathrm{T}^{\mathrm{CD} 8+}$ & \\
\hline IFNy-secreting $\mathrm{CD}^{+} \mathrm{CD}^{+} 6^{+} \mathrm{CIK}$ cells & & $\mathrm{CD}^{+}{ }^{+} \mathrm{CD} 56^{+} \mathrm{IFNy}^{+}$ & $\mathrm{CD}^{+}{ }^{+} \mathrm{CD} 56^{+}$ & $\mathrm{CIK}^{\mathrm{CD} 56+} \mathrm{IFNy}^{+} / \mathrm{CIK}^{\mathrm{CD} 56+}$ & \\
\hline IFNy-secreting $\mathrm{CD}^{+} \mathrm{CD} 161^{+} \mathrm{CIK}$ cells & & $\mathrm{CD}^{+}{ }^{+} \mathrm{CD} 161^{+} \mathrm{IFNy}^{+}$ & $\mathrm{CD}^{+}{ }^{+} \mathrm{CD} 161^{+}$ & $\mathrm{CIK}^{\mathrm{CD} 161+} \mathrm{IFNy}^{+} / \mathrm{CIK}^{\mathrm{CD} 161+}$ & \\
\hline IFNy-secreting $\mathrm{CD}^{-}{ }^{-} \mathrm{CD} 56^{+} \mathrm{NK}$ cells & & $\mathrm{CD}^{-}{ }^{-} \mathrm{CD} 56^{+} \mathrm{IFNy}^{+}$ & $\mathrm{CD}^{-}{ }^{-} \mathrm{CD} 56^{+}$ & $\mathrm{NK}^{\mathrm{CD} 56+} \mathrm{IFNy}^{+} / \mathrm{NK}^{\mathrm{CD} 56+}$ & \\
\hline IFNy-secreting $\mathrm{CD}^{-} \mathrm{CD} 161^{+} \mathrm{NK}$ cells & & $\mathrm{CD}^{-}{ }^{-} \mathrm{CD} 161^{+} \mathrm{IFNy}^{+}$ & $\mathrm{CD}^{-} \mathrm{CD} 161^{+}$ & $\mathrm{NK}^{\mathrm{CD} 161+} \mathrm{IFNy}^{+} / \mathrm{NK}^{\mathrm{CD} 161+}$ & \\
\hline IFNy-secreting $6 \mathrm{~B} 11^{+}{ }^{+}$NKT cells & & $6 \mathrm{~B} 11^{+} \mathrm{IFNy}^{+}$ & $6 \mathrm{~B} 11^{+}$ & $\mathrm{iNKT}^{+} \mathrm{IFNy}^{+} / \mathrm{iNKT}^{+}$ & \\
\hline
\end{tabular}

Surface marker combinations for flow cytometric staining and analysis.

DCs, monocytes, B cells, T cells, NK cells, CIK cells, and iNKT cells. Abbreviations of all cell types are given in Table 2 .

Cells were stained with various monoclonal antibodies (moAbs) labelled with fluorescein isothiocyanate (FITC), phycoerythrin (PE), phycoerythrin-cyanine7 tandem conjugate (PE-Cy7), or allophycocyanin (APC). Antibodies were provided by Beckman Coulter $^{\mathrm{a}}$ (Krefeld, Germany), Becton Dickinson ${ }^{\mathrm{b}}$ (Heidelberg,
Germany), Miltenyi Biotec ${ }^{c}$ (Bergisch Gladbach, Germany), BioLegend $^{\mathrm{d}}$ (Koblenz, Germany), and Santa Cruz Biotechnology ${ }^{\mathrm{e}}$ (Heidelberg, Germany). For analyses FITC-conjugated moAbs

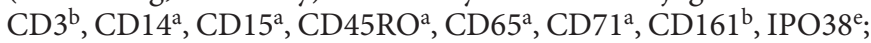
PE-conjugated moAbs CD3 ${ }^{\mathrm{a}}, \mathrm{CD} 4^{\mathrm{b}}, \mathrm{CD} 34^{\mathrm{a}}, \mathrm{CD} 56^{\mathrm{a}}, \mathrm{CD}^{\circ} 5^{\mathrm{c}}, \mathrm{CD} 80^{\mathrm{a}}$, $6 \mathrm{~B} 11^{\mathrm{b}}, \mathrm{IFNy}^{\mathrm{d}}$; PE-Cy7-conjugated moAbs $\mathrm{CD} 3^{\mathrm{a}}, \mathrm{CD} 4^{\mathrm{a}}, \mathrm{CD} 14^{\mathrm{b}}$, $\mathrm{CD}_{3}{ }^{\mathrm{a}}, \mathrm{CD} 34^{\mathrm{a}}, \mathrm{CD}^{\mathrm{c}}{ }^{\mathrm{c}}, \mathrm{CD} 117^{\mathrm{a}}, \mathrm{CD} 197^{\mathrm{b}}$; APC-conjugated moAbs 
Table 3. DC/DCleu-generating protocols

\begin{tabular}{|c|c|c|c|c|c|}
\hline $\mathrm{DC} / \mathrm{DC}_{\mathrm{leu}}$ & $\mathrm{DC} / \mathrm{DC}_{\mathrm{leu}}$ & Composition (total) & Time of & \multicolumn{2}{|c|}{ Time of culture Reference } \\
\hline Pici-PGE1 & MNC & $\begin{array}{l}\text { GM-CSF } 500 \mathrm{U} / \mathrm{mL} \\
\mathrm{IL}-4250 \mathrm{U} / \mathrm{mL} \\
\mathrm{OK}-43210 \mu \mathrm{g} / \mathrm{mL} \\
\mathrm{PGE}_{1} 1 \mu \mathrm{g} / \mathrm{mL}\end{array}$ & $\begin{array}{l}\text { d0 } \\
\text { d0 } \\
\text { d7 } \\
\text { d7 }\end{array}$ & 9 days & [38] \\
\hline Kit-I & WB & $\begin{array}{l}\text { GM-CSF } 800 \mathrm{U} / \mathrm{mL} \\
\mathrm{OK}-43210 \mu \mathrm{g} / \mathrm{mL}\end{array}$ & $\begin{array}{l}\mathrm{d} 0, \mathrm{~d} 2-3 \\
\mathrm{~d} 0, \mathrm{~d} 2-3\end{array}$ & $7-8$ days & $\begin{array}{l}\text { [Unpublished data] } \\
\text { European Patent No. } \\
15801987.7-1118\end{array}$ \\
\hline Kit-M & WB & $\begin{array}{l}\text { GM-CSF } 800 \mathrm{U} / \mathrm{mL} \\
\mathrm{PGE}_{1} 1 \mu \mathrm{g} / \mathrm{mL}\end{array}$ & $\begin{array}{l}\mathrm{d} 0, \mathrm{~d} 2-3 \\
\mathrm{~d} 0, \mathrm{~d} 2-3\end{array}$ & $7-8$ days & $\begin{array}{l}\text { [Unpublished data] } \\
\text { European Patent No. } \\
15801987.7-1118\end{array}$ \\
\hline Mode of action & $\begin{array}{l}\text { GM-CSF } \\
\text { IL-4 } \\
\text { OK-432 } \\
\text { PGE }_{1}\end{array}$ & $\begin{array}{l}\text { Induction of myeloid and DC differentiation } \\
\text { Induction of DC differentiation } \\
\text { Danger signalling, stimulation of DC differentiation } \\
\text { Danger signalling, stimulation of DC maturation and } \\
\text { migration (via CCR7 expression) }\end{array}$ & & & {$[16,38]$} \\
\hline
\end{tabular}

GM-CSF, granulocyte-macrophage colony-stimulating factor; IL-4, interleukin 4; OK-432, Picibanil; PGE 1 , prostaglandin $\mathrm{E}_{1}$; d day.

$\mathrm{CD}^{\mathrm{a}}, \mathrm{CD} 14^{\mathrm{a}}, \mathrm{CD} 19^{\mathrm{a}}, \mathrm{CD} 34^{\mathrm{a}}, \mathrm{CD} 56^{\mathrm{a}}, \mathrm{CD} 69^{\mathrm{b}}, \mathrm{CD} 117^{\mathrm{a}}, \mathrm{CD} 206^{\mathrm{b}}$ $6 \mathrm{~B} 11^{\mathrm{d}}$ were used. Non-viable cells were detected with $7 \mathrm{AAD}^{\mathrm{b}}$.

In preparation of staining, erythrocytes in WB samples were lysed using lysing buffer (Becton Dickinson) according to the manufacturer's instructions. Staining was performed by a $15-\mathrm{min}$ incubation of cells with the corresponding moAbs in the dark at room temperature using a staining medium containing 95\% PBS (Biochrom, Berlin, Germany) and 5\% FCS (Biochrom). Intracellular staining (e.g., IPO38, IFNy) was performed with the FIX\&PERM Cell Fixation and Cell Permeabilisation Kit (Thermo Fisher Scientific, Darmstadt, Germany).

Stained cells were analysed with the fluorescence-activated cell sorting flow cytometer FACS Calibur (Becton Dickinson) and the acquisition and analysis software CellQuestPro (Becton Dickinson). Isotype controls were conducted according to the manufacturer's instructions.

\section{Sample Preparation}

MNC were isolated from WB by density gradient centrifugation using the Ficoll-Hypague technique and a separating solution with a density of $1.077 \mathrm{~g} / \mathrm{mL}$ (Biocoll, Biochrom). T cells were isolated from MNC using the MACS microbead and column-based immunomagnetic cell separation technology (Miltenyi Biotec) via positive selection of $\mathrm{CD}^{+}$cells according to the manufacturer's instructions. Purity of isolated T cells was on average $80.5 \%$ (range 57.7-95.3\%). MNC and T cells, unless directly used, were frozen with 70\% RPMI-1640 medium (Biochrom), 20\% human serum (HealthCare Europa GmbH, Vienna, Austria), 10\% dimethyl sulfoxide (Sigma Aldrich Chemie GmbH, Steinheim, Germany), stored at $-80^{\circ} \mathrm{C}$ and thawed when required.

\section{Dendritic Cell Culture}

The generation of $\mathrm{DC} / \mathrm{DC}_{\text {leu }}$ was performed by the stimulation of MNC or WB with specific response modifiers, including granulocyte-macrophage colony-stimulating factor (GM-CSF) (SanofiAventis, Frankfurt, Germany), interleukin 4 (IL-4) (PeproTech, Berlin, Germany), Picibanil (OK-432) (Chugai Pharmaceutical Co., Kajiwara, Japan), and prostaglandin E1 ( $\mathrm{PGE}_{1}$ ) (PeproTech). Com-

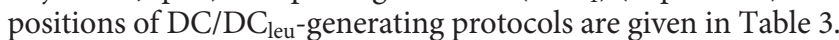

$\mathrm{DC} / \mathrm{DC}_{\text {leu }}$ from healthy and leukaemic $\mathrm{MNC}$ were generated with the $\mathrm{DC} / \mathrm{DC}_{\mathrm{leu}}$-generating protocol Pici-PGE1 [38]. For this, $3-4 \times 10^{6} \mathrm{MNC}$ were cultured in 12-multiwell culture plates (ThermoFisher Scientific) and diluted with $2 \mathrm{~mL} \mathrm{x}$-vivo 15 medium (Lonza, Basel, Switzerland). Response modifiers were added to the cultures (further referred to as $\mathrm{MNC}^{\mathrm{DC}(\mathrm{P})}$ ) according to the protocol. A culture without added response modifiers served as negative control $\left(\mathrm{MNC}^{\mathrm{DC}(\mathrm{Control})}\right)$. A half-medium exchange was carried out every 2-3 days. Cells were harvested after 9 days.

$\mathrm{DC} / \mathrm{DC}_{\text {leu }}$ from healthy and leukaemic $\mathrm{WB}$ were generated with the $\mathrm{DC} / \mathrm{DC}_{\mathrm{leu}}$-generating protocols Kit-I and Kit-M [unpublished data] [38]. For this, $500 \mu \mathrm{L} \mathrm{WB}$ (corresponding to 5.0-30.3 $\times 10^{6} \mathrm{MNC}$ ) were cultured in 24-multiwell culture plates (ThermoFisher Scientific) and diluted with $500 \mu \mathrm{L}$ x-vivo 15 medium. Response modifiers were added to the cultures (further referred to as $\left.\mathrm{WB}^{\mathrm{DC}(\mathrm{I})}, \mathrm{WB}^{\mathrm{DC}(\mathrm{M})}\right)$ according to the protocol. Likewise, a culture without added response modifiers served as negative control $\left(\mathrm{WB}^{\mathrm{DC}(\mathrm{Control})}\right)$. Cells were harvested after 7-8 days.

DC cultures as well as subsequent mixed lymphocyte cultures (MLC) were incubated at $37^{\circ} \mathrm{C}, 21 \% \mathrm{O}_{2}$, and $5 \% \mathrm{CO}_{2}$. In some cases, additional cultures were incubated simultaneously in hypoxia-like conditions $\left(37^{\circ} \mathrm{C}, 10 \% \mathrm{O}_{2}, 10 \% \mathrm{CO}_{2}\right)$.

Flow cytometric analyses of leukaemic blasts, $\mathrm{DC}, \mathrm{DC}_{\text {leu }}$, and $\mathrm{DC}_{\text {mat }}$ were performed before and after dendritic cell culture

Fig. 1. Flow cytometric analyses. A Conversion of myeloid blasts into $\mathrm{DC}_{\text {leu }}$ through blastmodulatory Kit-I and Kit-M. Exemplary plots show $\mathrm{DC}_{\text {leu }}$, characterised by the co-expression of the blast marker CD117 and the DC marker CD206, in uncultured WB, $\mathrm{WB}^{\mathrm{DC}(\mathrm{Control})}$, $\mathrm{WB}^{\mathrm{DC}(\mathrm{M})}$, and $\mathrm{WB}^{\mathrm{DC}(\mathrm{I})}$. B Gain of maturation through Kit-I and -M. Exemplary plots show $\mathrm{DC}_{\mathrm{mat}}$, characterised by the co-expression of the DC marker CD206 and the maturation marker CCR7, in $\mathrm{WB}^{\mathrm{DC}(\text { Control) }}, \mathrm{WB}^{\mathrm{DC}(\mathrm{M})}$, and $\mathrm{WB}^{\mathrm{DC}(\mathrm{I})}$. C Gating of IFNy-secreting $\mathrm{T}^{\mathrm{CD} 3+}\left(\mathrm{CD}^{+} \mathrm{IFNy}^{+}\right), \mathrm{T}^{\mathrm{CD} 4+}\left(\mathrm{CD}^{+} \mathrm{CD}^{+} \mathrm{IFNy}^{+}\right)$, and $\mathrm{T}^{\mathrm{CD} 8+}\left(\mathrm{CD}^{+} \mathrm{CD}^{-} \mathrm{IFNy}^{+}\right)$cells as detected by CSA D Comparison of IFNy-secreting $\mathrm{T}^{\mathrm{CD} 3+}\left(\mathrm{CD}^{+} \mathrm{IFNy}^{+}\right)$cells in $\mathrm{WB}^{\mathrm{DC}(\mathrm{Control})-\mathrm{MLC}}, \mathrm{WB}^{\mathrm{DC}(\mathrm{M})-\mathrm{MLC}}$, and $\mathrm{WB}^{\mathrm{DC}(\mathrm{I})-\mathrm{MLC}}$. Abbreviations of all cell types are given in Table 2 .

(For figure see next page.)
Klauer et al. 


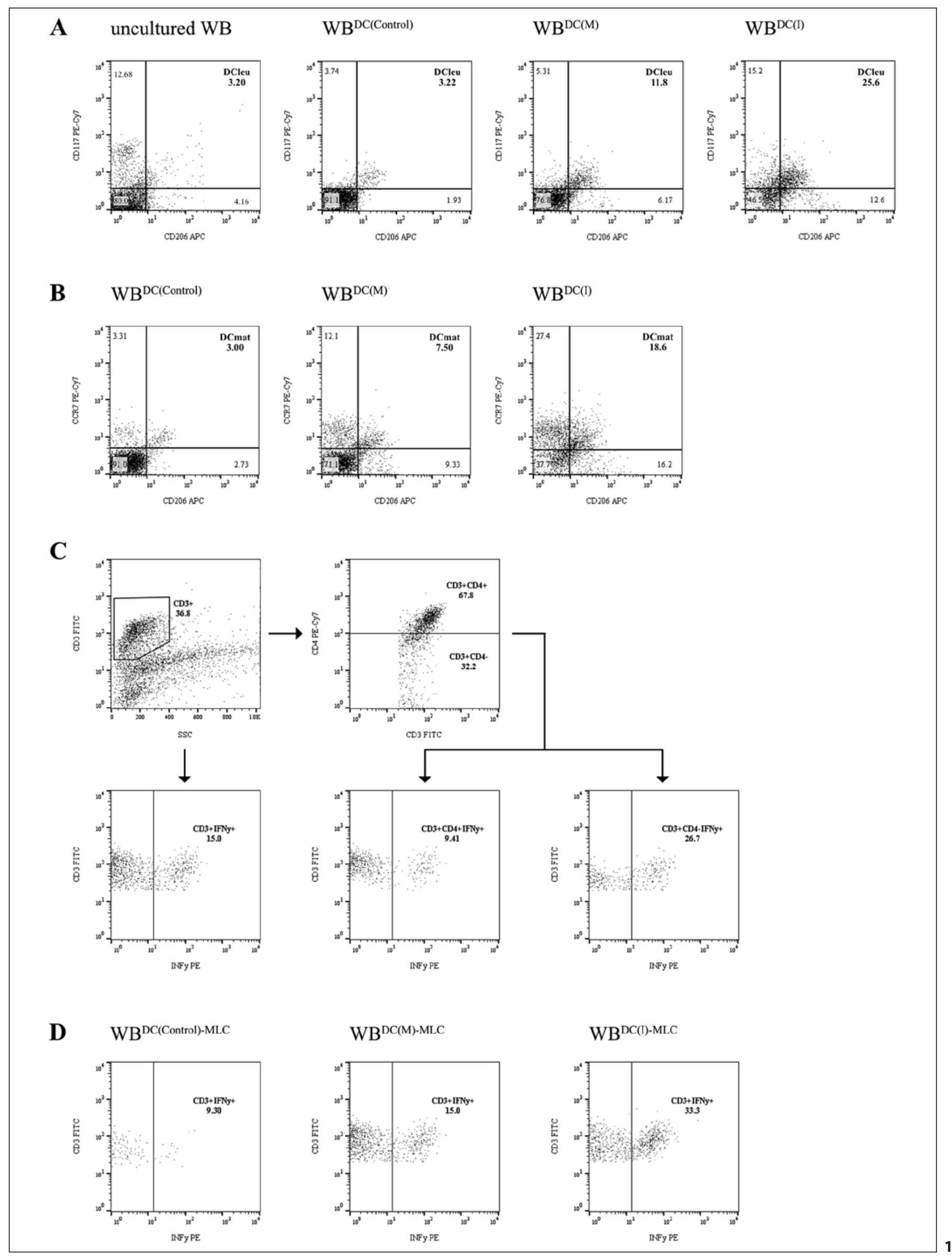


(DCC) using a refined gating strategy [unpublished data] [16, 17, 39]. $\mathrm{DC}_{\text {leu }}$ were analysed by the co-expression of at least one blast marker (CD15, CD34, CD65, CD117) including lineage-aberrant markers (CD 56) and one DC marker that had not been expressed on naive blasts (CD80, CD206; of which CD80 qualified in 82.4\%, CD206 in $94.1 \%$, and both CD80 and CD206 in 76.5\% of cases). Maturation of $\mathrm{DC} / \mathrm{DC}_{\text {leu }}$ was analysed by the further co-expression of CCR7 (Fig. 1A, B). Premise for DC subgroup analyses was the presence of $\geq 5 \%$ DCs in the total cell fraction.

We conducted preliminary experiments to assess the feasibility and comparability of $\mathrm{DC} / \mathrm{DC}_{\text {leu }}$ generation in different settings. As these experiments and previous studies [unpublished data] [38, 40] affirmed the feasibility and comparability with Pici-PGE1 in healthy and leukaemic MNC, with Kit-I and Kit-M in healthy and leukaemic WB, as well as under hypoxia-like and normoxia-like conditions (data not shown), further experiments were conducted on leukaemic WB to adapt to more physiological conditions, under normoxia-like conditions.

\section{Mixed Lymphocyte Culture}

Consecutive generation of $\mathrm{T}$ cell-enriched immunoreactive cells was performed by the stimulation of autologous $\mathrm{T}$ cells with $\mathrm{DC} / \mathrm{DC}_{\text {leu }}$-containing $\mathrm{MNC}^{\mathrm{DC}}$ or $\mathrm{WB}^{\mathrm{DC}}$.

Based on a MNC model, $1 \times 10^{6} \mathrm{~T}$ cells and a fraction of $\mathrm{MNC}^{\mathrm{DC}}$ containing $0.25 \times 10^{6} \mathrm{DC} / \mathrm{DC}_{\text {leu }}$ were co-cultured in a 24 -multiwell culture plate (total cell count 1.7-4.8 $\times 10^{6} \mathrm{MNC}$ ) and diluted in 1 mL RMPI-1640 medium containing $100 \mathrm{U} / \mathrm{mL}$ penicillin (Biochrom) and $15 \%$ human serum. $50 \mathrm{U} / \mathrm{mL}$ IL-2 were added on day 0 and day $2-3$ to all cultures (further referred to as MNC ${ }^{\mathrm{DC}(\mathrm{P})-\mathrm{MLC}}$, $\left.\mathrm{MNC}^{\mathrm{DC}(\mathrm{Control})-\mathrm{MLC}}\right)$. A half-medium exchange was carried out every 2-3 days. Cells were harvested after 7-9 days.

Based on a WB model, $1 \times 10^{6} \mathrm{~T}$ cells and a fraction of $\mathrm{WB}^{\mathrm{DC}}$ containing $0.25 \times 10^{6} \mathrm{DC} / \mathrm{DC}_{\text {leu }}$ were co-cultured in a 24 -multiwell culture plate (total cell count 1.8-9.4 $\times 10^{6} \mathrm{MNC}$ ) and diluted in $1 \mathrm{~mL}$ RMPI-1640 medium containing $100 \mathrm{U} / \mathrm{mL}$ penicillin. $50 \mathrm{U} /$ mL IL-2 were added on day 0 and day 2-3 to all cultures (further referred to as $\mathrm{WB}^{\mathrm{DC}(\mathrm{I})-\mathrm{MLC}}, \mathrm{WB}^{\mathrm{DC}(\mathrm{M})-\mathrm{MLC}}, \mathrm{WB}^{\mathrm{DC}(\text { Control)-MLC})}$. Cells were harvested after 6-7 days.

Flow cytometric analyses of T-cell subsets were performed before and after MLC using a refined gating strategy [18, 19, 41].

We conducted preliminary experiments to assess the feasibility and comparability of $\mathrm{DC} / \mathrm{DC}_{\mathrm{leu}}$ stimulation on immunoreactive cells and its resulting anti-leukaemic cytotoxicity in different settings. As these experiments affirmed the feasibility and comparability in (healthy and) leukaemic MNC and WB (data not shown), further experiments were conducted on leukaemic WB to adapt to more physiological conditions.

\section{Cytotoxity Fluorolysis Assay}

A fluorolysis assay was performed to analyse the lytic activity of $\mathrm{T}$ cell-enriched immunoreactive cells against leukaemic blasts (further referred to as anti-leukaemic cytotoxicity) of $\mathrm{MNC}^{\mathrm{DC}-\mathrm{MLC}}$ and $\mathrm{WB}^{\mathrm{DC}-\mathrm{MLC}}[18]$. Therefore, a fraction of MNC $\mathrm{MC}^{\mathrm{DLC}}$ and $\mathrm{WB}^{\mathrm{DC}-\mathrm{MLC}}$ containing $1 \times 10^{6} \mathrm{~T}$ cells (effector cells) and $1 \times 10^{6}$ thawed autologous leukaemic blasts (target cells) were co-cultured (total cell count 2.3-6.0 × 10 $0^{6} \mathrm{MNC}$ ) diluted in $1 \mathrm{~mL}$ RMPI-1640 medium containing $100 \mathrm{U} / \mathrm{mL}$ penicillin and $15 \%$ human serum for 3 and $24 \mathrm{~h}$ at $37^{\circ} \mathrm{C}, 21 \% \mathrm{O}_{2}, 5 \% \mathrm{CO}_{2}$. Target cells were stained with FITC-, PE-, or APC-conjugated blast-specific moAbs before culture, and with 7AAD and a defined number of fluorosphere beads (Beckman Coulter) after culture when harvested. All assays were performed in combination with a control, for which effector and target cells were cultured analogously but separated and only merged prior to flow cytometric analyses.
Flow cytometric analyses were performed using a refined gating strategy [18]. Achieved anti-leukaemic cytotoxicity is described as "blast lysis" defined as the percentual difference of viable target cells between the effector-target cell culture and the control, "cases with blast lysis" defined as the proportion of cases with blast lysis $>0 \%$, "improved blast lysis" defined as the percentual difference of the blast lysis of $\mathrm{WB}^{\mathrm{DC}(\mathrm{I})-\mathrm{MLC}}$ or $\mathrm{WB}^{\mathrm{DC}(\mathrm{M})-\mathrm{MLC}}$ and $\mathrm{WB}^{\mathrm{DC}(\mathrm{Control}) \mathrm{MLC}}$, and "cases with improved blast lysis" defined as the proportion of cases with improved blast lysis $>0 \%$.

\section{Cytokine Secretion Assay}

For the detection of IFNy-secreting cells in MNC, MNC ${ }^{\mathrm{DC}}$ $\mathrm{MLC}, \mathrm{WB}$ and $\mathrm{WB}^{\mathrm{DC}-\mathrm{MLC}}$, an IFNy secretion assay (Miltenyi Biotec) was performed. According to the manufacturer's instructions, cells were firstly labelled with an IFNy Catch Reagent (Miltenyi Biotec), a bi-specific moAB directed against the panleukocytic marker CD45 and IFNy. By connecting to leukocytes during a non-IFNy-secretion period (10 min, on ice), followed by connecting to IFNy during an IFNy-secretion period (45 min, $37^{\circ} \mathrm{C}$ ), IFNy could be bound to the positive secreting cells. For detection by flow cytometry, cells were secondly labelled with an IFNy-specific PE-conjugated IFNy Detection Antibody (Miltenyi Biotec).

In some cases, an additional stimulation of MNC, MNC ${ }^{\text {DC-MLC }}$ $\mathrm{WB}$, and $\mathrm{WB}^{\mathrm{DC}-\mathrm{MLC}}$ was performed prior to the CSA, for which cells were incubated for $4 \mathrm{~h}$ with a leukaemia-associated antigen (LAA) suspension containing $50 \mu \mathrm{g} / \mathrm{mL}$ WT-1 (Miltenyi Biotec) and $50 \mu \mathrm{g} / \mathrm{mL}$ PRAME (Miltenyi Biotec) or with $1 \mu \mathrm{g} / \mathrm{mL}$ staphylococcal enterotoxin B (SEB, Sigma Aldrich Chemie GmbH).

For flow cytometric analyses of IFNy-secreting cells, cells were co-stained with FITC-, PE-Cy7-, and APC-conjugated moAbs. Analyses of IFNy-secreting T, NK, CIK, and iNKT cells were performed with a gating strategy described in Figure 1C, D.

We conducted preliminary experiments to assess the feasibility of the CSA in different settings. As these experiments affirmed the feasibility in uncultured and cultured, healthy and leukaemic, MNC and WB, as well as under hypoxia-like and normoxia like conditions, with comparability in MNC and WB and under hypoxia-like and normoxia-like conditions (data not shown), further experiments were conducted on leukaemic WB to adapt to more physiological conditions, under normoxia-like conditions.

\section{Intracellular Cytokine Assay}

For the detection of intracellular IFNy in $\mathrm{WB}$ and $\mathrm{WB}^{\mathrm{DC}-\mathrm{MLC}}$, an intracellular cytokine assay was performed. To avoid cytokine secretion during the assay, cells were firstly incubated with brefeldin A (1000X, BioLegend) concentrated at 1:1,000 for $15 \mathrm{~h}$. Intracellular staining of IFNy subsequently was procured using the FIX\&PERM Cell Fixation and Cell Permeabilisation Kit according to the manufacturer's instructions. For flow cytometric analysis of IFNy-producing cells, cells were co-stained with FITC-, PE-Cy7-, and APC-conjugated moAbs. Analyses of IFNy-secreting T, NK, CIK, and iNKT cells were performed with the same gating strategy as used for the CSA.

\section{Statistical Methods}

Data is presented as mean \pm standard deviation (SD). Statistical comparisons for two groups were performed using the two-tailed $t$ test and the Pearson correlation coefficient. Significance was defined as "not significant" (n.s.) with $p$ values $>0.10$, as "borderline significant" with $p$ values 0.10 to 0.05 , and as "significant" with $p$ values $<0.05$. Correlation was defined as "negligible" with $r$ values 0.00 to 0.30 ( -0.00 to -0.30 ), as "low" with $r$ values 0.30 to 0.50 ( -0.30 to -0.50$)$, as "moderate" with $r$ values 0.50 to 0.70 ( -0.50 to 


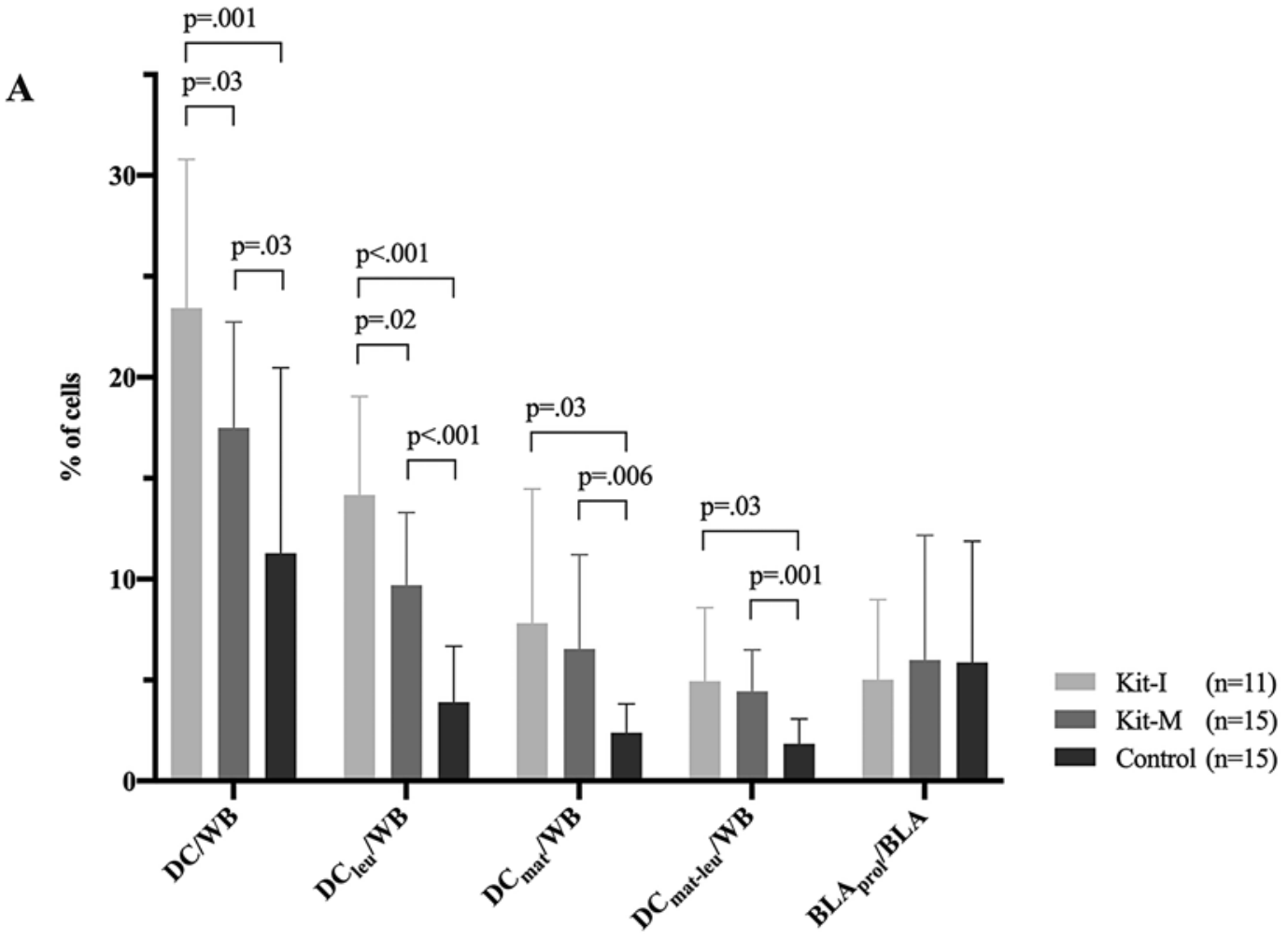

B

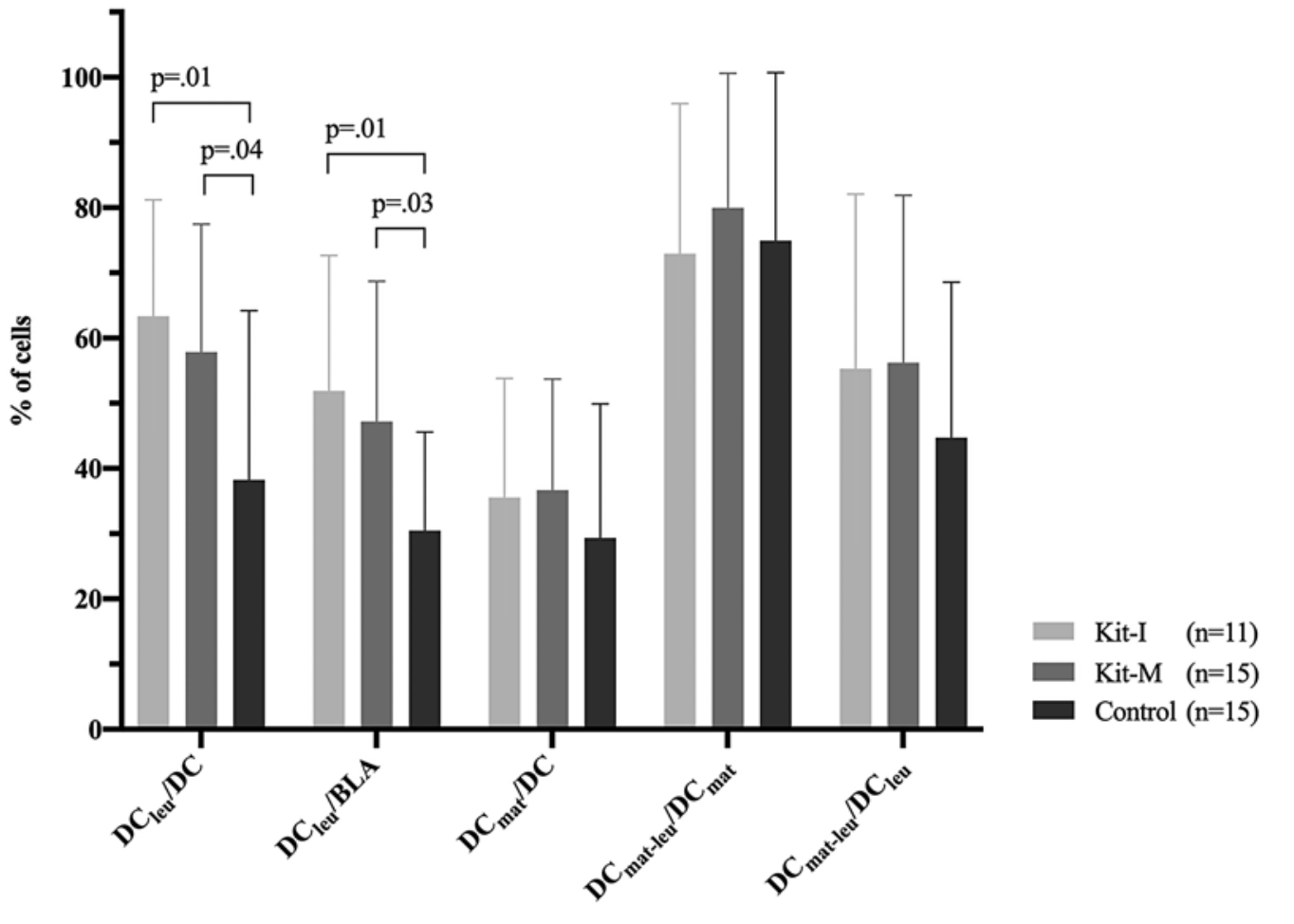

Fig. 2. Generation of (mature) DC and $D_{C_{l e u}}$ from leukaemic WB with blastmodulatory Kit-I and Kit-M without induction of blast proliferation. Given are the mean \pm SD of DC, $\mathrm{DC}_{\text {leu }}, \mathrm{DC}_{\text {mat }}$, and $\mathrm{DC}_{\text {mat-leu }}$ in the WB fraction and $\mathrm{BLA}_{\text {prol }}$ in the blast fraction in $\mathrm{WB}^{\mathrm{DC}(\mathrm{I})}, \mathrm{WB}^{\mathrm{DC}(\mathrm{M})}$, and $\mathrm{WB}^{\mathrm{DC}(\mathrm{Control})}(\mathbf{A})$, and the mean $\pm \mathrm{SD}$ of $\mathrm{DC}_{\text {leu }}$ in the $\mathrm{DC}$ and blast fraction, $\mathrm{DC}_{\text {mat }}$ in the $\mathrm{DC}$ fraction, and $\mathrm{DC}_{\text {mat-leu }}$ in the $\mathrm{DC}_{\text {mat }}$ and $\mathrm{DC}_{\text {leu }}$ fraction in $\mathrm{WB} \mathrm{BC}^{\mathrm{DC}(\mathrm{I})}$, $\mathrm{WB}^{\mathrm{DC}(\mathrm{M})}$, and $\mathrm{WB}^{\mathrm{DC}(\text { Control) }}(\mathbf{B})$. Statistically significant $(p$ values $<0.05)$ and borderline significant $(p$ values 0.10 to 0.05 ) differences are given. Abbreviations of all cell types are given in Table 2. 
$-0.70)$, and as "high" with $r$ values 0.70 to $1.00(-0.70$ to -1.00$)$. Statistical analyses and figures were implemented with GraphPad Prism 8 (GraphPad Software, California, USA) and Pages 8.2 (Apple, California, USA).

\section{Results}

Generation of Mature DC/DC $C_{\text {leu }}$ from Leukaemic WB without Induction of Blast Proliferation

We were able to generate significantly higher frequencies of DC/WB and $\mathrm{DC}_{\text {leu }} / \mathrm{WB}$ with Kit-I and Kit-M compared to control, with significantly higher frequencies in $\mathrm{WB}^{\mathrm{DC}(\mathrm{I})}$ than $\mathrm{WB}^{\mathrm{DC}(\mathrm{M})}$. Differentiating $\mathrm{DC}_{\text {leu }}$ in its subgroups showed significantly higher frequencies of $\mathrm{DC}_{\text {leu }} /$ $\mathrm{BLA}$ as well as of $\mathrm{DC}_{\text {leu }} / \mathrm{DC}$ in $\mathrm{WB}^{\mathrm{DC}(\mathrm{I})}$ and $\mathrm{WB}^{\mathrm{DC}(\mathrm{M})}$ compared to $\mathrm{WB}^{\mathrm{DC}(\mathrm{Control})}$. Frequencies of $\mathrm{DC}_{\text {leu }} / \mathrm{BLA}$ and $\mathrm{DC}_{\text {leu }} / \mathrm{DC}$ did not differ significantly in $\mathrm{WB}^{\mathrm{DC}(\mathrm{I})}$ compared to $\mathrm{WB}^{\mathrm{DC}(\mathrm{M})}$ (Fig. 1A, 2A, B).

We furthermore evaluated the maturation of $\mathrm{DC}$ and found significantly higher frequencies of $\mathrm{DC}_{\text {mat }} / \mathrm{WB}$ and $\mathrm{DC}_{\text {mat-leu }} / \mathrm{WB}$ and no significantly different frequencies of $\mathrm{DC}_{\text {mat }} / \mathrm{DC}$ in $\mathrm{WB}^{\mathrm{DC}(\mathrm{I})}$ and $\mathrm{WB}^{\mathrm{DC}(\mathrm{M})}$ compared to $\mathrm{WB}^{\mathrm{DC}(\mathrm{Control})}$. Differentiating $\mathrm{DC}_{\text {mat-leu }}$ in its subgroups showed no significantly different frequencies of $\mathrm{DC}_{\text {mat-leu }} / \mathrm{DC}_{\text {mat }}$ and no significantly different frequencies of $\mathrm{DC}_{\text {mat-leu }} / \mathrm{DC}_{\text {leu }}$ in $\mathrm{WB}^{\mathrm{DC}(\mathrm{I})}$ and $\mathrm{WB}^{\mathrm{DC}(\mathrm{M})}$ compared to $\mathrm{WB}^{\mathrm{DC}(\text { Control) }}$. Frequencies of $\mathrm{DC}_{\text {mat }}$ and $\mathrm{DC}_{\text {mat-leu }}$ in depicted cell groups did not differ significantly in $\mathrm{WB}^{\mathrm{DC}(\mathrm{I})}$ compared to $\mathrm{WB}^{\mathrm{DC}(\mathrm{M})}$ (Fig. $1 \mathrm{~B}, 2 \mathrm{~A}, \mathrm{~B}$ ).

Reviewing the effect of Kits on the proliferation of non-converted blasts during DCC, we found no significant shift of $\mathrm{BLA}_{\text {prol }} / \mathrm{BLA}$ in $\mathrm{WB}^{\mathrm{DC}(\mathrm{I})}$ and $\mathrm{WB}^{\mathrm{DC}(\mathrm{M})}$ compared to $\mathrm{WB}^{\mathrm{DC}(\text { Control) }}$ (Fig. 2A).

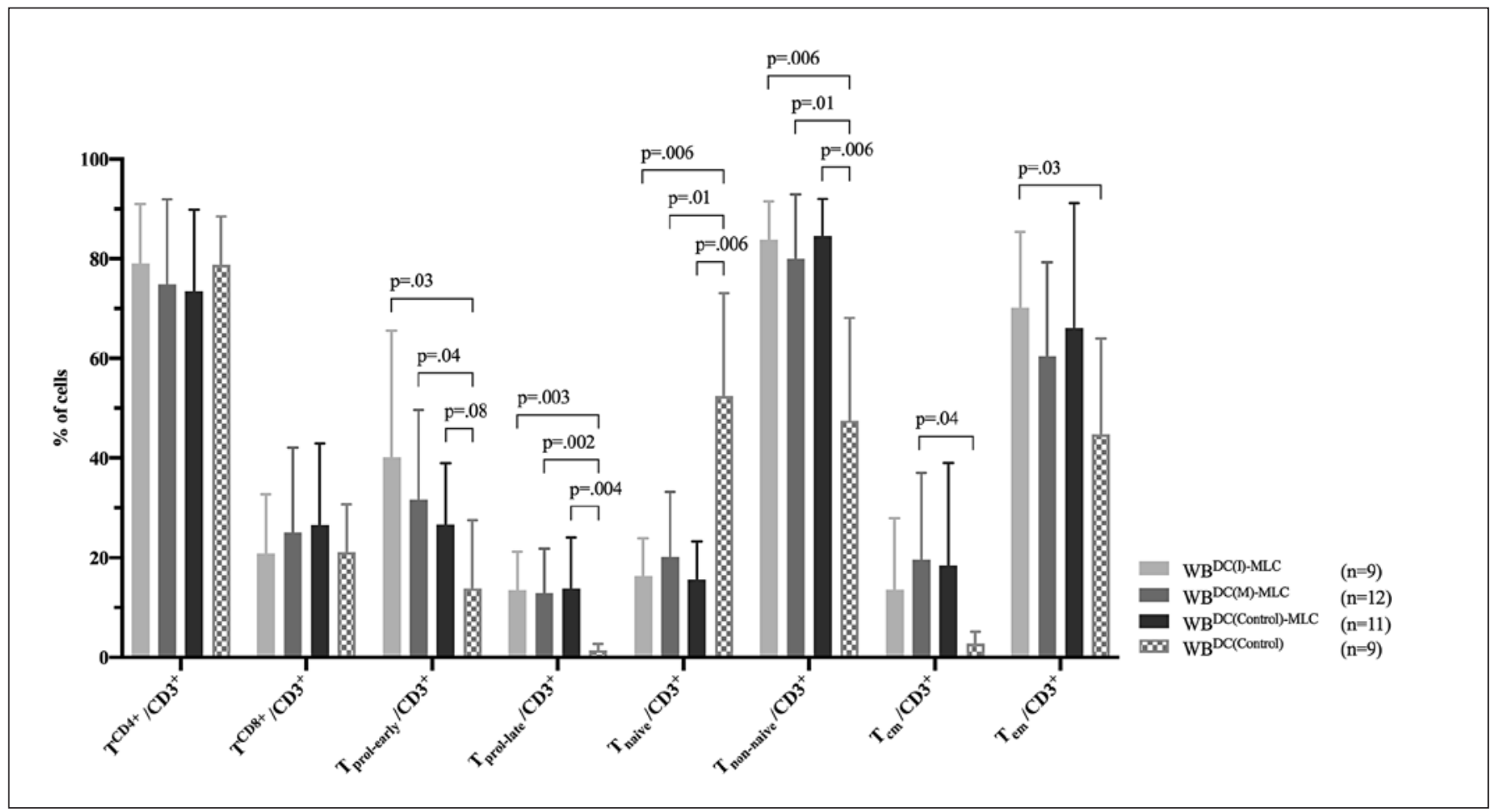

Fig. 3. Stimulatory effect of $\mathrm{DC} / \mathrm{DC}_{\mathrm{leu}}$ on the composition of immunoreactive cells. Given are the mean \pm $\mathrm{SD}$ of T-cell subsets in the $\mathrm{CD}^{+}$cell fraction before $\left(\mathrm{WB}^{\mathrm{DC}(\text { Control) })}\right.$ ) and after $\left(\mathrm{WB}^{\mathrm{DC}(\mathrm{I})-\mathrm{MLC}}\right.$, $\left.\mathrm{WB}^{\mathrm{DC}(\mathrm{M})-\mathrm{MLC}}, \mathrm{WB}^{\mathrm{DC}(\text { Control)-MLC }}\right) \mathrm{DC}^{\mathrm{D}} \mathrm{DC}_{\text {leu }}$ stimulation. Statistically significant $(p$ values $<0.05)$ and borderline significant ( $p$ values 0.10 to 0.05 ) differences are given. Abbreviations of all cell types are given in Table 2.

Fig. 4. Stimulatory effect of $\mathrm{DC} / \mathrm{DC}_{\mathrm{leu}}$ on the cytotoxic activity of immunoreactive cells as measured by CTX. Given are the proportions of cases with blast lysis ("\% cases with blast lysis") and the mean \pm range of lysed blasts ("\% lysed blasts") in WB ${ }^{\mathrm{DC}(\mathrm{I})-\mathrm{MLC}}, \mathrm{WB}^{\mathrm{DC}(\mathrm{M})-\mathrm{MLC}}$, and WB ${ }^{\mathrm{DC}(\text { Control)-MLC }}$ after $3 \mathrm{~h}(\mathbf{A})$ and $24 \mathrm{~h} \mathrm{(C)}$, and the "best" achieved blast lysis after $3 \mathrm{~h}$ or $24 \mathrm{~h}(\mathbf{E})$; the proportions of cases with an improvement in blast lysis ("\% cases with improved blast lysis") and the mean \pm range of improved lysed blasts ("\% improved lysed blasts") in $\mathrm{WB} \mathrm{B}^{\mathrm{DC}(\mathrm{I}) \text { - }}$ ${ }^{\mathrm{MLC}}$ and $\mathrm{WB}^{\mathrm{DC}(\mathrm{M})-\mathrm{MLC}}$ in relation to $\mathrm{WB}^{\mathrm{DC}(\mathrm{Control})-\mathrm{MLC}}$ after $3 \mathrm{~h}(\mathbf{B})$ and $24 \mathrm{~h}(\mathbf{D})$, and the "best" achieved improvement in blast lysis after $3 \mathrm{~h}$ or $24 \mathrm{~h} \mathrm{(F).}$

(For figure see next page.) 


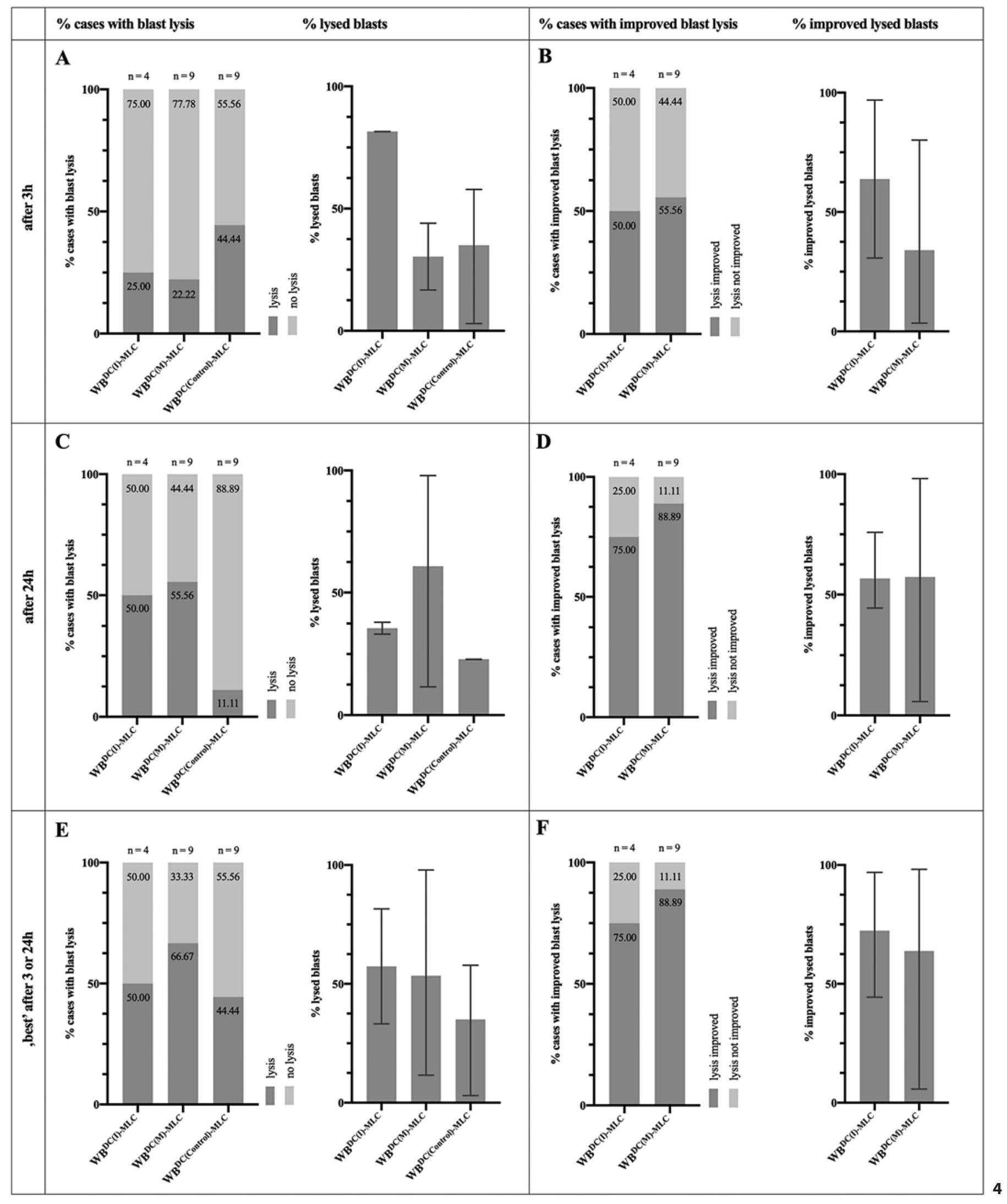




\section{Stimulatory Impact of $D C / D C_{\text {leu }}$ on $T$ Cell-Enriched} Immunoreactive Cells

$\mathrm{DC} / \mathrm{DC}_{\text {leu }}$ and IL-2 Stimulation Increases T-Cell

\section{Activation}

To assess the potential stimulating effect of generated $\mathrm{DC} / \mathrm{DC}_{\text {leu }}$ on immunoreactive cells in the presence of IL-2, T-cell compositions were compared before $\left(\mathrm{WB}^{\mathrm{DC}(\text { Control) })}\right.$ and after $\left(\mathrm{WB}^{\mathrm{DC}(\mathrm{I})-\mathrm{MLC}}, \mathrm{WB}^{\mathrm{DC}(\mathrm{M})-\mathrm{MLC}}\right.$, $\mathrm{WB}^{\mathrm{DC}(\text { Control)-MLC) }}$ MLC. Frequencies of $\mathrm{T}^{\mathrm{CD} 4+}, \mathrm{T}^{\mathrm{CD} 8+}$, $\mathrm{T}_{\text {prol-early }}, \mathrm{T}_{\text {prol-late, }}, \mathrm{T}_{\text {naive }}, \mathrm{T}_{\text {non-naive }}, \mathrm{T}_{\mathrm{cm}}$, and $\mathrm{T}_{\text {eff }}$ cells were analysed in reference to $\mathrm{T}^{\mathrm{CD} 3+}$ cells.

We noticed a generally higher activation status of cells in $\mathrm{WB}^{\mathrm{DC}(\mathrm{I})-\mathrm{MLC}}, \mathrm{WB}^{\mathrm{DC}(\mathrm{M})-\mathrm{MLC}}$ as well as in $\mathrm{WB}^{\mathrm{DC}(\text { Control)-MLC }}$ compared to $\mathrm{WB}^{\mathrm{DC}(\text { Control) }}$, characterised by a significant increase of early and late proliferating $\mathrm{T}$ cells, a significant shift from naive to non-naive $\mathrm{T}$ cells, and a (significant) increase of central and effector memory $\mathrm{T}$ cells. $\mathrm{T}^{\mathrm{CD} 4+}$ and $\mathrm{T}^{\mathrm{CD} 8+}$ cells did not show any significant transformations. When comparing $\mathrm{WB}^{\mathrm{DC}(\mathrm{I})-\mathrm{MLC}}, \mathrm{WB}^{\mathrm{DC}(\mathrm{M})-\mathrm{MLC}}$, and $\mathrm{WB}^{\mathrm{DC}(\text { Control)-MLC }}$, no significant differences in $\mathrm{T}$ cell compositions could be found (Fig. 3).

\section{$\mathrm{DC} / \mathrm{DC}_{\text {leu }}$ Stimulation Increases Anti-Leukaemic}

Cytotoxicity

We analysed the lytic activity of $\mathrm{WB}^{\mathrm{DC}(\mathrm{I})-\mathrm{MLC}}$, $\mathrm{WB}^{\mathrm{DC}(\mathrm{M})-\mathrm{MLC}}$, and $\mathrm{WB}^{\mathrm{DC}(\text { Control)-MLC }}$ through CTX after 3 $\mathrm{h}$ and $24 \mathrm{~h}$ of incubation of effector and leukaemic target cells, to assess the anti-leukaemic cytotoxicity of DC/ $\mathrm{DC}_{\mathrm{leu}}$-stimulated immunoreactive cells.

As early as $3 \mathrm{~h}$, we could observe a lysis of target cells in $\mathrm{WB}^{\mathrm{DC}(\mathrm{I})-\mathrm{MLC}}$ as well as $\mathrm{WB}^{\mathrm{DC}(\mathrm{M})-\mathrm{MLC}}$ in about a quarter of the cases, but in $\mathrm{WB}^{\mathrm{DC}(\text { Control)-MLC }}$ in about a half of the cases. Average frequencies of lysed blasts were (n.s.) higher in $\mathrm{WB}^{\mathrm{DC}(\mathrm{I})-\mathrm{MLC}}$ than in $\mathrm{WB}^{\mathrm{DC}(\mathrm{M}) \text {-MLC }}$ and $\mathrm{WB}^{\mathrm{DC}}$ (Control)-MLC (Fig. 4A). After $24 \mathrm{~h}$, more cases of $\mathrm{WB}^{\mathrm{DC}(\mathrm{I})-\mathrm{MLC}}$ and $\mathrm{WB}^{\mathrm{DC}(\mathrm{M})-\mathrm{MLC}}$, but less cases of $\mathrm{WB}^{\mathrm{DC}(\mathrm{Control})-\mathrm{MLC}}$ attained lysis. Average frequencies of lysed blasts decreased (n.s.) in $\mathrm{WB}^{\mathrm{DC}(\mathrm{I})-\mathrm{MLC}}$ and $\mathrm{WB}^{\mathrm{DC}(\mathrm{Control})-\mathrm{MLC}}$, but increased (n.s.) in $\mathrm{WB}^{\mathrm{DC}(\mathrm{M})-\mathrm{MLC}}$, whereby frequencies in $\mathrm{WB}^{\mathrm{DC}(\mathrm{I})-\mathrm{MLC}}$ and $\mathrm{WB}^{\mathrm{DC}(\mathrm{M})-\mathrm{MLC}}$

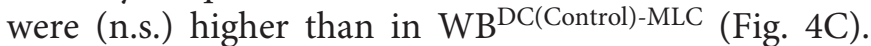
Notably, in cases without lysis, frequencies of blasts showed no significant difference between $\mathrm{WB}^{\mathrm{DC}(\mathrm{I})-\mathrm{MLC}}$, $\mathrm{WB}^{\mathrm{DC}(\mathrm{M})-\mathrm{MLC}}$, and $\mathrm{WB}^{\mathrm{DC}(\text { Control)-MLC }}$.

Concerning the lysis of target cells in $\mathrm{WB}^{\mathrm{DC}(\mathrm{I})-\mathrm{MLC}}$ and $\mathrm{WB}^{\mathrm{DC}(\mathrm{M})-\mathrm{MLC}}$ in relation to $\mathrm{WB}^{\mathrm{DC}(\text { Control)-MLC }}$, after $3 \mathrm{~h}$, we could observe an improvement in lysis in $\mathrm{WB}^{\mathrm{DC}(\mathrm{I})-\mathrm{MLC}}$ as well as $\mathrm{WB}^{\mathrm{DC}(\mathrm{M})-\mathrm{MLC}}$ in about half of the cases. Average improved lysed blasts were (n.s.) higher in $\mathrm{WB}^{\mathrm{DC}(\mathrm{I})-\mathrm{MLC}}$ than in $\mathrm{WB}^{\mathrm{DC}(\mathrm{M}) \text {-MLC }}$ (Fig. 4B). After $24 \mathrm{~h}$, more cases of $\mathrm{WB}^{\mathrm{DC}(\mathrm{I})-\mathrm{MLC}}$ and $\mathrm{WB}^{\mathrm{DC}(\mathrm{M})-\mathrm{MLC}}$ attained an improvement in lysis. Average improved lysed blasts in $\mathrm{WB}^{\mathrm{DC}(\mathrm{M})-\mathrm{MLC}}$ thereby increased (n.s.) to levels of $\mathrm{WB}^{\mathrm{DC}(\mathrm{I})-\mathrm{MLC}}$ (Fig. 4D).
Notably, in cases without an improvement in lysis, frequencies of blasts showed no significant difference between $\mathrm{WB}^{\mathrm{DC}(\mathrm{I})-\mathrm{MLC}}$ and $\mathrm{WB}^{\mathrm{DC}(\mathrm{M}) \text {-MLC }}$.

Overall, choosing the best anti-leukaemic cytotoxicity after 3 or $24 \mathrm{~h}$, we found higher numbers of cases with lysis in $\mathrm{WB}^{\mathrm{DC}(\mathrm{M})-\mathrm{MLC}}$ than in $\mathrm{WB}^{\mathrm{DC}(\mathrm{I})-\mathrm{MLC}}$ and $\mathrm{WB}^{\mathrm{DC}(\mathrm{Control})-\mathrm{MLC}}$. Average frequencies of lysed blasts were (n.s.) higher in $\mathrm{WB}^{\mathrm{DC}(\mathrm{I})-\mathrm{MLC}}$ and $\mathrm{WB}^{\mathrm{DC}(\mathrm{M}) \text {-MLC }}$ than

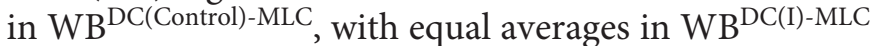
and $\mathrm{WB}^{\mathrm{DC}(\mathrm{M})-\mathrm{MLC}}$ (Fig. $\left.4 \mathrm{E}\right) . \quad \mathrm{WB}^{\mathrm{DC}(\mathrm{I})-\mathrm{MLC}}$ and $\mathrm{WB}^{\mathrm{DC}(\mathrm{M})-\mathrm{MLC}}$ attained equal proportions of cases with an improvement in lysis and equal averages of improved lysed blasts (Fig. 4F). There was no significant difference in the frequencies of blasts in cases without lysis between $\mathrm{WB}^{\mathrm{DC}(\mathrm{I})-\mathrm{MLC}}, \mathrm{WB}^{\mathrm{DC}(\mathrm{M})-\mathrm{MLC}}$, and $\mathrm{WB}^{\mathrm{DC}(\text { Control)-MLC }}$ and in cases without an improvement in lysis between $\mathrm{WB}^{\mathrm{DC}(\mathrm{I})-\mathrm{MLC}}$ and $\mathrm{WB}^{\mathrm{DC}(\mathrm{M})-\mathrm{MLC}}$.

\section{Stimulatory Impact of $D C / D C_{\text {leu }}$ on the IFNy Secretion} of T Cell-Enriched Immunoreactive Cells Detected via CSA

Analysis of IFNy Secretion

The IFNy secretion of innate and adaptive immune cells was determined through CSA before (uncultured $\mathrm{WB})$ and after $\left(\mathrm{WB}^{\mathrm{DC}(\mathrm{I})-\mathrm{MLC}}, \mathrm{WB}^{\mathrm{DC}(\mathrm{M})-\mathrm{MLC}}\right.$, $\mathrm{WB}^{\mathrm{DC}(\text { Control)-MLC})} \mathrm{DC} / \mathrm{DC}_{\text {leu }}$ stimulation. Frequencies of IFNy-secreting $\mathrm{T}^{\mathrm{CD} 3+}, \mathrm{T}^{\mathrm{CD} 4+}, \mathrm{T}^{\mathrm{CD} 8+}, \mathrm{CIK}^{\mathrm{CD} 56+}, \mathrm{NK}^{\mathrm{CD} 56+}$, $\mathrm{CIK}^{\mathrm{CD} 161+}, \mathrm{NK}^{\mathrm{CD} 161+}$, and iNKT cells were analysed.

No Spontaneous Activation of Immunoreactive Cells during DCC and MLC

We compared frequencies of IFNy-secreting immunoreactive cells in uncultured WB to $\mathrm{WB}^{\mathrm{DC}(\text { Control)-MLC }}$, to assess the effect of cultivation (DCC and MLC). We found low frequencies of IFNy-secreting cells in uncultured $\mathrm{WB}$. Comparing uncultured $\mathrm{WB}$ to $\mathrm{WB}^{\mathrm{DC}(\text { Control)-MLC }}$ showed no significant differences, besides significantly lower frequencies of $\mathrm{NK}^{\mathrm{CD} 161+}+\mathrm{IFNy}^{+} / \mathrm{NK}^{\mathrm{CD} 161+}$ in

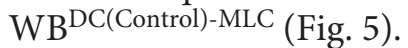

$\mathrm{DC} / \mathrm{DC}_{\mathrm{leu}}$ Stimulation Increases IFNy Secretion of Adaptive and Innate Immunoreactive Cells

To assess the effect of $\mathrm{DC} / \mathrm{DC}_{\text {leu }}$ stimulation on the secretion of IFNy, we compared frequencies of IFNysecreting immunoreactive cells in $\mathrm{WB}^{\mathrm{DC}(\mathrm{I})-\mathrm{MLC} \text {, }}$ $\mathrm{WB}^{\mathrm{DC}(\mathrm{M})-\mathrm{MLC}}$ to uncultured $\mathrm{WB}$ as well as to $\mathrm{WB}^{\mathrm{DC}(\text { Control)-MLC }}$

Regarding cells of the adaptive immune system, we found significantly higher frequencies of $\mathrm{T}^{\mathrm{CD} 3}+\mathrm{IFNy}^{+} /$ $\mathrm{T}^{\mathrm{CD} 3+}$ in $\mathrm{WB}^{\mathrm{DC}(\mathrm{I})-\mathrm{MLC}}$ and $\mathrm{WB}^{\mathrm{DC}(\mathrm{M})-\mathrm{MLC}}$ compared to uncultured $\mathrm{WB}$ and $\mathrm{WB}^{\mathrm{DC}(\text { Control)-MLC, with }}$ $\mathrm{WB}^{\mathrm{DC}(\mathrm{I})-\mathrm{MLC}}$ holding significantly higher frequencies than $\mathrm{WB}^{\mathrm{DC}(\mathrm{M})-\mathrm{MLC}}$. Moreover, we could detect significantly higher frequencies of $\mathrm{T}^{\mathrm{CD} 4+} \mathrm{IFNy}^{+} / \mathrm{T}^{\mathrm{CD} 4+}$ and 


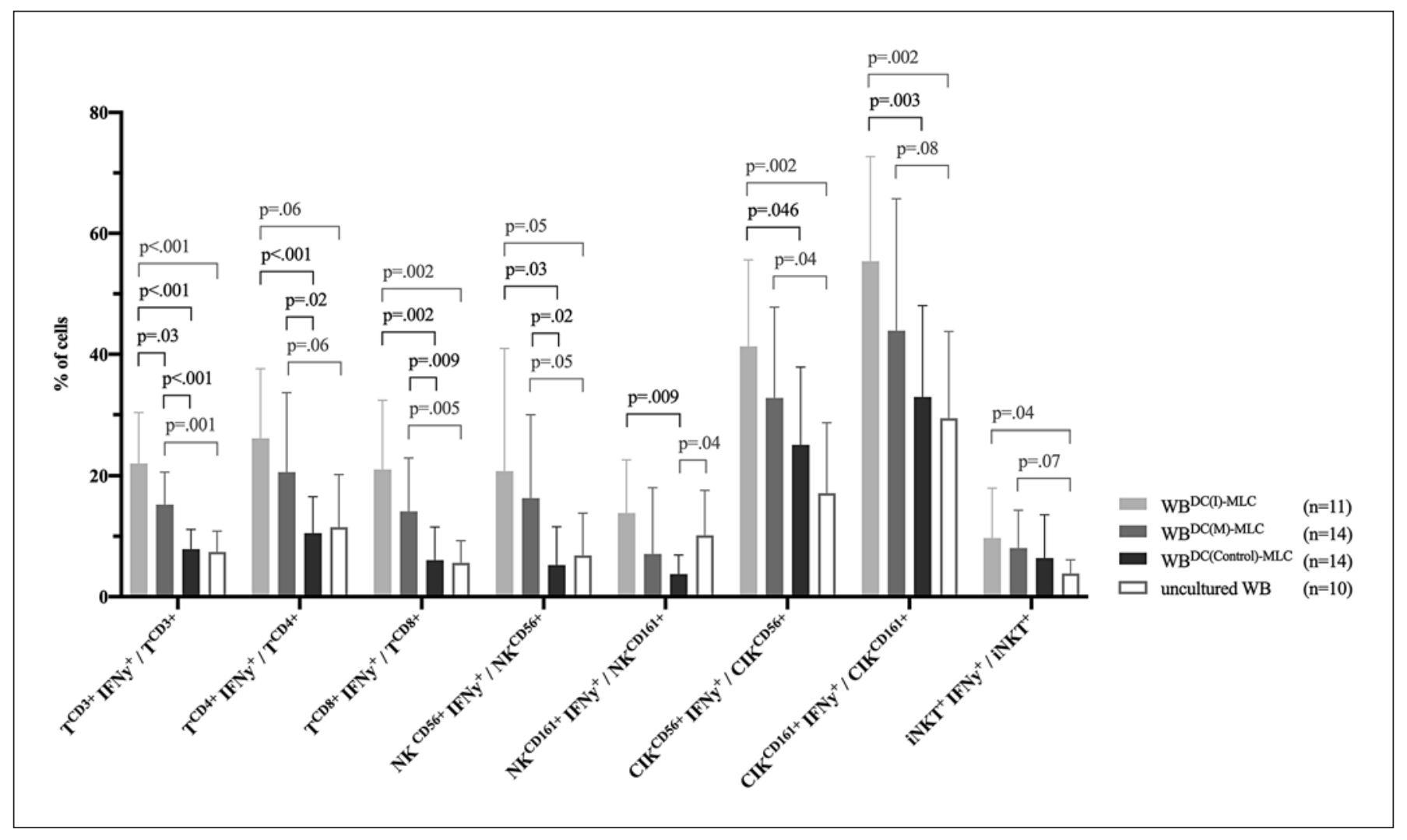

Fig. 5. IFNy secretion of immunoreactive cells before (uncultured $\mathrm{WB}$ ) and after ( $\mathrm{WB}^{\mathrm{DC}(\mathrm{I})-\mathrm{MLC}}, \mathrm{WB}^{\mathrm{DC}(\mathrm{M})-\mathrm{MLC}}$, $\left.\mathrm{WB}^{\mathrm{DC}(\mathrm{Control})-\mathrm{MLC}}\right) \mathrm{DC} / \mathrm{DC}_{\text {leu }}$ stimulation as measured by CSA. Given are the mean $\pm \mathrm{SD}$ of frequencies of IFNysecreting T, NK, CIK, and iNKT cells. Statistically significant $(p$ values $<0.05)$ and borderline significant $(p$ values 0.10 to 0.05 ) differences are given. Abbreviations of all cell types are given in Table 2.

$\mathrm{T}^{\mathrm{CD} 8+} \mathrm{IFNy}^{+} / \mathrm{T}^{\mathrm{CD} 8+}$ in $\mathrm{WB}^{\mathrm{DC}(\mathrm{I})-\mathrm{MLC}}$ and $\mathrm{WB}^{\mathrm{DC}(\mathrm{M})-\mathrm{MLC}}$ compared to uncultured $\mathrm{WB}$ and $\mathrm{WB}^{\mathrm{DC}(\text { Control)-MLC }}$. Frequencies of both cell groups were (n.s.) higher in $\mathrm{WB}^{\mathrm{DC}(\mathrm{I})-\mathrm{MLC}}$ compared to $\mathrm{WB}^{\mathrm{DC}(\mathrm{M})-\mathrm{MLC}}$ (Fig. 1C, 5).

Regarding cells of the innate immune system, we found (significantly) higher frequencies of $\mathrm{NK}^{\mathrm{CD} 56+} \mathrm{IFNy}^{+} /$ $\mathrm{NK}^{\mathrm{CD} 56+}$ and $\mathrm{NK}^{\mathrm{CD} 161+} \mathrm{IFNy}^{+} / \mathrm{NK}^{\mathrm{CD} 161+}$ in $\mathrm{WB}^{\mathrm{DC}(\mathrm{I})-\mathrm{MLC}}$ and $\mathrm{WB}^{\mathrm{DC}(\mathrm{M})-\mathrm{MLC}}$ compared to uncultured $\mathrm{WB}$ and $\mathrm{WB}^{\mathrm{DC}(\text { Control)-MLC}}$, beside $\mathrm{NK}^{\mathrm{CD} 161+}{ }^{2} \mathrm{FNy}^{+} / \mathrm{NK}^{\mathrm{CD} 161+}$ showing no significant difference compared to uncul-

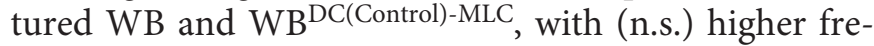
quencies in $\mathrm{WB}^{\mathrm{DC}(\mathrm{I})-\mathrm{MLC}}$ than $\mathrm{WB}^{\mathrm{DC}(\mathrm{M})-\mathrm{MLC}}$. Moreover, we could detect (significantly) higher frequencies of $\mathrm{CIK}^{\mathrm{CD} 56+} \mathrm{IFNy}^{+} / \mathrm{CIK}^{\mathrm{CD} 56+}$ and $\mathrm{CIK}^{\mathrm{CD} 161+} \mathrm{IFNy}^{+} /$ $\mathrm{CIK}^{\mathrm{CD} 161+}$ in $\mathrm{WB}^{\mathrm{DC}(\mathrm{I})-\mathrm{MLC}}$ and $\mathrm{WB}^{\mathrm{DC}(\mathrm{M}) \text {-MLC }}$ compared to

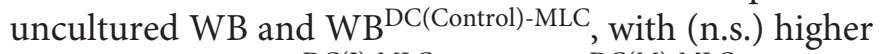
frequencies in $\mathrm{WB}^{\mathrm{DC}(\mathrm{I})-\mathrm{MLC}}$ than $\mathrm{WB}^{\mathrm{DC}(\mathrm{M})-\mathrm{MLC}}$. No significant differences could be found in the frequencies of $\mathrm{iNKT}^{+} \mathrm{IFNy}^{+} / \mathrm{iNKT}^{+}$in $\mathrm{WB}^{\mathrm{DC}(\mathrm{I})-\mathrm{MLC}}$ and $\mathrm{WB}^{\mathrm{DC}(\mathrm{M}) \text {-MLC }}$ compared to $\mathrm{WB}^{\mathrm{DC}(\text { Control)-MLC, }}$, though compared to uncultured WB (Fig. 5).
No Impact of Age, Sex, and Blast Frequency on

Stimulation of IFNy Secretion

Overall, the stimulation of IFNy secretion was possible with both $\mathrm{DC} / \mathrm{DC}_{\mathrm{leu}}-$ Kit-I and -Kit-M and independent from patients' age, sex, or blast frequency (data not shown).

LAA Stimulation Does Not Further Increase IFNy Secretion of $\mathrm{DC} / \mathrm{DC}_{\mathrm{leu}}$-Stimulated Immunoreactive Cells

To assess whether $\mathrm{DC} / \mathrm{DC}_{\mathrm{leu}}$-stimulated adaptive immunoreactive cells have been subject to LAA-dependent activation, we added the two LAA WT-1 and PRAME to uncultured $\mathrm{WB}, \mathrm{WB}^{\mathrm{DC}(\mathrm{I})-\mathrm{MLC}}, \mathrm{WB}^{\mathrm{DC}(\mathrm{M})-\mathrm{MLC}}$, and $\mathrm{WB}^{\mathrm{DC}(\text { Control)-MLC}}$. The addition of LAA did (n.s.) increase frequencies of IFNy-secreting cells in uncultured WB and

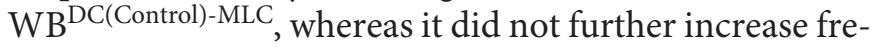
quencies of IFNy-secreting cells in $\mathrm{WB}^{\mathrm{DC}(\mathrm{I})-\mathrm{MLC}}$ and $\mathrm{WB}^{\mathrm{DC}(\mathrm{M})-\mathrm{MLC}}$ (data not shown).

Positive Correlation of IFNy-Positive Immunoreactive Cells Obtained by CSA and ICA

In order to validate frequencies of IFNy-producing immunoreactive cells obtained by CSA, we performed 
IFNy production obtained by CSA vs ICA $r=.793 \quad p<.001$

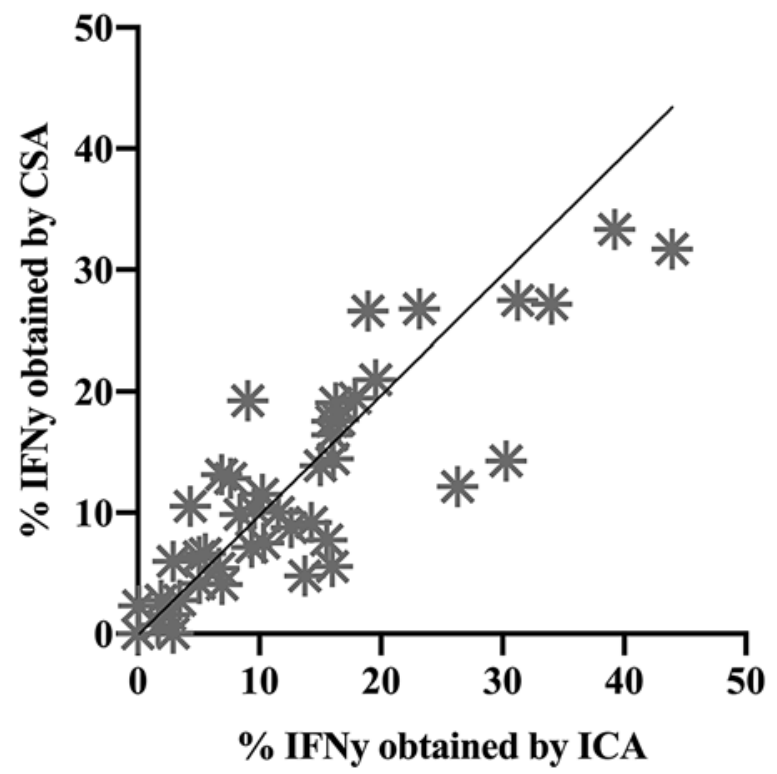

Fig. 6. Correlation of the IFNy production of immunoreactive cells $\left(\mathrm{T}^{\mathrm{CD} 3+}, \mathrm{T}^{\mathrm{CD} 4+}, \mathrm{T}^{\mathrm{CD} 8+}, \mathrm{CIK}^{\mathrm{CD} 56+}, \mathrm{NK}^{\mathrm{CD} 56+}\right.$, iNKT cells) obtained by CSA and ICA. Statistically significant $(p$ values $<0.05)$ correlations are given. Abbreviations of all cell types are given in Table 2.

parallel ICAs and correlated the results. There was a significantly high positive correlation $(r=0.793)$ between frequencies obtained by CSA and frequencies obtained by ICA (Fig. 6). Both the CSA and ICA hereby yielded comparable frequencies of IFNy-positive $\mathrm{T}^{\mathrm{CD} 3+}, \mathrm{T}^{\mathrm{CD} 4+}, \mathrm{T}^{\mathrm{CD} 8+}$, $\mathrm{CIK}^{\mathrm{CD} 56+}, \mathrm{NK}^{\mathrm{CD} 56+}$, and iNKT cells.

\section{Positive Correlation of IFNy Secretion and Anti- \\ Leukaemic Cytotoxicity of $D C / D C_{\text {leu }}$-Stimulated Immunoreactive Cells}

To assess the relationship between the IFNy secretion and anti-leukaemic cytotoxicity of $\mathrm{DC} / \mathrm{DC}_{\mathrm{leu}}$-stimulated immunoreactive cells, we correlated the absolute improvement of IFNy secretion with the relative improvement of blast lysis (= improved blast lysis) in $\mathrm{WB}^{\mathrm{DC}(\mathrm{M})-\mathrm{MLC}}$ in proportion to $\mathrm{WB}^{\mathrm{DC}(\text { Control)-MLC }}$. Unfortunately, both groups could not be correlated in $\mathrm{WB}^{\mathrm{DC}(\mathrm{I})-\mathrm{MLC}}$ due to low case numbers.

The IFNy secretion did not correlate with anti-leukaemic cytotoxicity after $3 \mathrm{~h}$, but after $24 \mathrm{~h}$ : within the adaptive immune cells, we found a significantly moderate positive correlation between $\mathrm{T}^{\mathrm{CD} 3+} \mathrm{IFNy}^{+} / \mathrm{T}^{\mathrm{CD} 3+}$ and blast lysis $(r=$ $0.600)$ and between $\mathrm{T}^{\mathrm{CD} 8+} \mathrm{IFNy}^{+} / \mathrm{T}^{\mathrm{CD} 8+}$ and blast lysis $(r=$ 0.596 ), and a significantly high positive correlation between $\mathrm{T}^{\mathrm{CD} 4+} \mathrm{IFNy}^{+} / \mathrm{T}^{\mathrm{CD} 4+}$ and blast lysis $(r=0.716)$ (Fig. 7A-C). Moreover, within the innate immune cells, we found a sig- nificantly high positive correlation between $\mathrm{NK}^{\mathrm{CD} 56+} \mathrm{IFNy}^{+} /$ $\mathrm{NK}^{\mathrm{CD} 56+}$ and blast lysis $(r=0.976)$. Other innate immune cells showed no further significant correlations (Fig. 7D).

\section{Discussion}

\section{DC-Based Immunotherapy for AML}

Based on the realisation that the immune system can be exploited to take control over AML, different immunological strategies have been developed to prompt a potent anti-leukaemic immunity. Here, targeted immunotherapeutic strategies relying on antibodies, engineered $\mathrm{T}$-cell receptors and $\mathrm{T}$ cells engineered to express chimeric antigen receptors have shown promising results [4244]. Targeted immunotherapy, however, depends on a competent target antigen to assure on-tumour effectivity but prevent off-tumour toxicity. Yet, selecting a proper leukaemic target antigen proves to be difficult due to a pervasive expression pattern overlapping with healthy tissues and haematopoiesis [10, 43, 45, 46]. However, there are strategies which are able to overcome this obstacle, most notably DC-based strategies. DCs generated from myeloid leukaemic blasts $\left(\mathrm{DC}_{\text {leu }}\right)$ are able to simultaneously express dendritic- and leukaemia-specific antigens and thereby prime and enhance leukaemia-specific immune responses with the whole leukaemic antigen repertoire ex and in vivo [11,47-52], breaking the burden of finding an appropriate target antigen.

\section{$D C / D C_{\text {leu }}$ Generation and Their Stimulatory Impact on the Anti-Leukaemic Activity of T Cell-Enriched Immunoreactive Cells}

We generated DC and $\mathrm{DC}_{\text {leu }}$ from leukaemic WB ex vivo with immunomodulatory Kit-I and Kit-M. Frequencies of $\mathrm{DC}$ and $\mathrm{DC}_{\text {leu }}$ were significantly higher in $\mathrm{WB}^{\mathrm{DC}(\mathrm{M})}$ and $\mathrm{WB}^{\mathrm{DC}(\mathrm{I})}$ compared to $\mathrm{WB}^{\mathrm{DC}(\mathrm{Control})}$, with significantly higher frequencies in $\mathrm{WB}^{\mathrm{DC}(\mathrm{I})}$ than $\mathrm{WB}^{\mathrm{DC}(\mathrm{M})}$. Both $\mathrm{DC}$ and $\mathrm{DC}_{\text {leu }}$ showed a significant proportion of mature DC. This stimulation of maturation and CCR7-dependent migration to lymph nodes, as achieved by Kit-I and Kit$\mathrm{M}$, is essential for $\mathrm{DC}$ and $\mathrm{DC}_{\text {leu }}$ to activate $\mathrm{T}$ cells and other immunoreactive cells [53-55]. Though both Kits are able to generate significant frequencies of $\mathrm{DC} / \mathrm{DC}_{\text {leu }}$, it appears that the combination of GM-CSF + Picibanil (OK-432) in Kit-I has a stronger danger signalling and stimulatory impact on DC differentiation than the combination of GM-CSF + $\mathrm{PGE}_{1}$ in Kit-M, but a similar stimulatory impact on DC maturation. Importantly, the proliferation of non-converted leukaemic blasts was not induced by Kit-I and Kit-M during DCC. All these findings have already been demonstrated in larger studies [unpublished data] [38, 39]. Comparable results were found under hypoxia-like conditions [40]. 
A

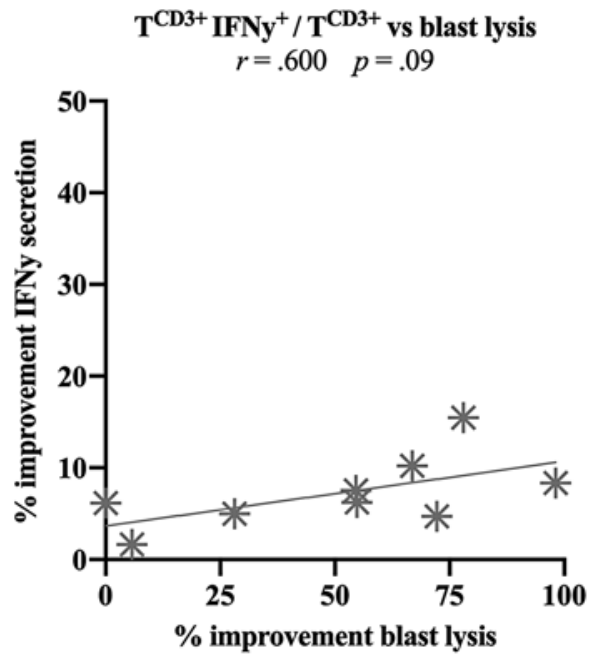

C

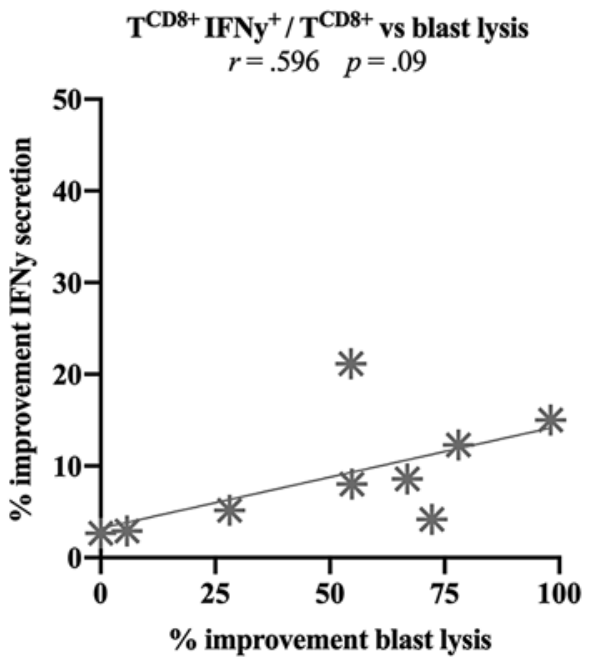

B

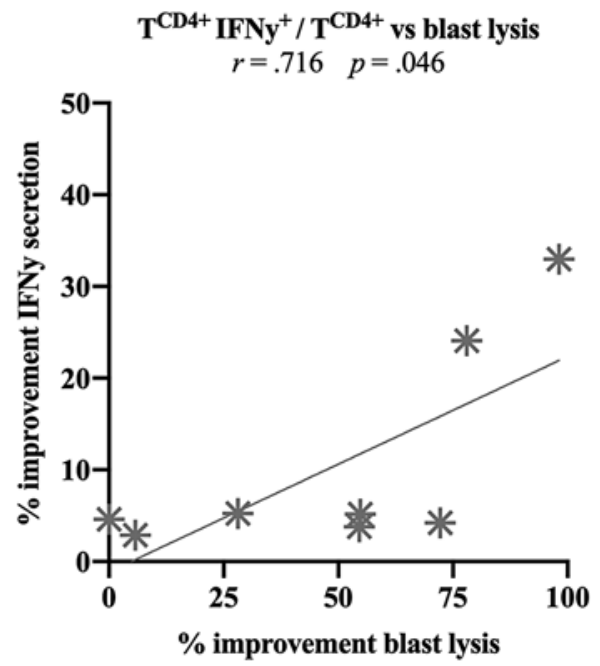

D

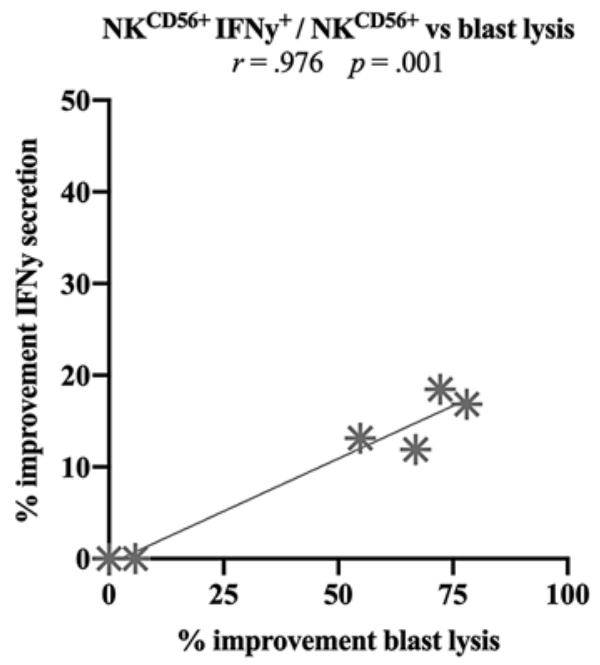

Fig. 7. Correlation of the absolute improvement of IFNy secretion with the relative improvement of blast lysis (= improved blast lysis) in $\mathrm{WB}^{\mathrm{DC}(\mathrm{M})-\mathrm{MLC}}$ compared to $\mathrm{WB}^{\mathrm{DC}(\text { Control)-MLC }}$. Given are the correlation of $\mathrm{T}^{\mathrm{CD} 3+} \mathrm{IFNy}^{+} /$ $\mathrm{T}^{\mathrm{CD} 3+}(\mathbf{A}), \mathrm{T}^{\mathrm{CD} 4+} \mathrm{IFNy}^{+} / \mathrm{T}^{\mathrm{CD} 4+}(\mathbf{B}), \mathrm{T}^{\mathrm{CD} 8+} \mathrm{IFNy}^{+} / \mathrm{T}^{\mathrm{CD} 8+}(\mathbf{C})$, and $\mathrm{NK}^{\mathrm{CD} 56+} \mathrm{IFNy}^{+} / \mathrm{NK}^{\mathrm{CD} 56+}$ (D) with blast lysis. Statistically significant $(p$ values $<0.05$ ) and borderline significant ( $p$ values 0.10 to 0.05 ) correlations are given. Abbreviations of all cell types are given in Table 2.

Through the stimulation of immunoreactive cells with $\mathrm{DC} / \mathrm{DC}_{\text {leu }}$ we could observe a generally higher activation status in $\mathrm{WB}^{\mathrm{DC}(\mathrm{I})-\mathrm{MLC}}, \mathrm{WB}^{\mathrm{DC}(\mathrm{M})-\mathrm{MLC}}$ as well as $\mathrm{WB}^{\mathrm{DC}(\text { Control)-MLC }}$ compared to $\mathrm{WB}^{\mathrm{DC}(\text { Control) }}$, characterised by a significant increase of proliferating $\mathrm{T}$ cells, a significant shift from naive to non-naive T-cell subsets, and a (significant) increase of central and effector memory $\mathrm{T}$ cells. This general transformation is most likely caused by the addition of IL-2 to all MLCs, as IL-2 triggers the proliferation and differentiation of $\mathrm{T}$ cells as well as the activation and differentiation of other immunoreactive cells [56]. In addition to that, previous larger studies, however, have found an increase of $\mathrm{T}^{\mathrm{CD} 8+}$ cells and a corresponding decrease of $\mathrm{T}^{\mathrm{CD} 4+}$ cells in $\mathrm{WB}^{\mathrm{DC}(\mathrm{I})-\mathrm{MLC}}$ and $\mathrm{WB}^{\mathrm{DC}(\mathrm{M})-\mathrm{MLC}}$ compared to $\mathrm{WB}^{\mathrm{DC}(\text { Control)-MLC }}$ and $\mathrm{WB}^{\mathrm{DC}(\text { Control) }}$ [38].

Even though the stimulation of immunoreactive cells with $\mathrm{DC} / \mathrm{DC}_{\text {leu }}$ had no impact on the composition of $\mathrm{T}$ cell subsets, it had an impact on the anti-leukaemic activity. We could demonstrate that the anti-leukemic cytotoxicity of immunoreactive cells could be notably improved through the stimulation with $\mathrm{DC} / \mathrm{DC}_{\mathrm{leu}}-\mathrm{Kit}-\mathrm{I}$ and -Kit-M in most of the cases. Interestingly, some cases achieved lysis or improved lysis after $3 \mathrm{~h}$ and some cases only after $24 \mathrm{~h}$, whereas average lysis was the highest in $\mathrm{WB}^{\mathrm{DC}(\mathrm{I})-\mathrm{MLC}}$ after $3 \mathrm{~h}$ and in $\mathrm{WB}^{\mathrm{DC}(\mathrm{M})-\mathrm{MLC}}$ after $24 \mathrm{~h}$. This occurrence might be due to different killing mechanisms 
of the immunoreactive cells: the early and fast-acting perforin-granzyme pathway and the late and slow-acting Fas/FasL pathway, which can run separately or synergistically $[21,22]$. WB ${ }^{\mathrm{DC}(\mathrm{I})-\mathrm{MLC}}$ hereby appears to perform via the former pathway, while $\mathrm{WB}^{\mathrm{DC}(\mathrm{M})-\mathrm{MLC}}$ appears to operate via the latter pathway. Overall, pooling the best antileukaemic cytotoxicity after 3 or $24 \mathrm{~h}, \mathrm{DC} / \mathrm{DC}_{\mathrm{leu}}-\mathrm{Kit}-\mathrm{I}$ and -Kit-M, however, appear to be equally efficient. Taken together, the CTX allows to quantify the acquired antileukaemic cytotoxicity, but it does not display participating cells of the immune response, like the CSA does.

Stimulatory Impact of $D C / D C_{\text {leu }}$ on the IFNy Secretion of T Cell-Enriched Immunoreactive Cells

$\mathrm{DC} / \mathrm{DC}_{\text {leu }}$ activate adaptive immune cells $\left(\mathrm{T}^{\mathrm{CD} 4+}, \mathrm{T}^{\mathrm{CD} 8+}\right)$ by presenting leukaemia-specific antigens over MHC class I and II [35] and presumably innate immune cells ( $\mathrm{NK}^{\mathrm{CD} 56+}$, $\mathrm{NK}^{\mathrm{CD} 161+}, \mathrm{CIK}^{\mathrm{CD} 56+}, \mathrm{CIK}^{\mathrm{CD} 161+}$, iNKT) by yet unknown MHC-unrestricted mechanisms [57, 58], thereby enhancing their effector mechanisms and IFN secretion, the latter also resulting in cross-stimulation. An increase of IFNy secretion upon $\mathrm{DC} / \mathrm{DC}_{\mathrm{leu}}$ stimulation can hence display functionally active leukaemia-specific cells.

With the CSA we were able to detect and phenotypically characterise IFNy-secreting adaptive and innate immunoreactive cells, and thereby evaluate the effect of $\mathrm{DC} / \mathrm{DC}_{\text {leu }}$ stimulation. Uncultured leukaemic $\mathrm{WB}$, as a starting point, already showed low frequencies of IFNy-secreting cells representing a physiological (and conceivably partially leukaemia-specific) immunological base activity. Through stimulation of immunoreactive cells by $\mathrm{DC} / \mathrm{DC}_{\mathrm{leu}}-\mathrm{Kit}-\mathrm{I}$ and $-\mathrm{Kit}-$ $\mathrm{M}$, we were able not only to increase the anti-leukaemic cytotoxicity, but also to significantly increase the IFNy secretion of adaptive immune cells $\left(\mathrm{T}^{\mathrm{CD} 3+}, \mathrm{T}^{\mathrm{CD} 4+}, \mathrm{T}^{\mathrm{CD} 8+}\right.$ cells) in $\mathrm{WB}^{\mathrm{DC}(\mathrm{I})-\mathrm{MLC}}$ and $\mathrm{WB}^{\mathrm{DC}(\mathrm{M})-\mathrm{MLC}}$ compared to uncultured $\mathrm{WB}$ as well as $\mathrm{WB}^{\mathrm{DC}(\text { Control)-MLC }}$. Further, the IFNy secretion of innate immune cells $\left(\mathrm{CIK}^{\mathrm{CD} 56+}, \mathrm{NK}^{\mathrm{CD} 56+}, \mathrm{CIK}^{\mathrm{CD} 161+}\right.$, $\mathrm{NK}^{\mathrm{CD} 161+}$ cells) was (significantly) increased in $\mathrm{WB}^{\mathrm{DC}(\mathrm{I})-\mathrm{MLC}}$ and $\mathrm{WB}^{\mathrm{DC}(\mathrm{M})-\mathrm{MLC}}$ compared to uncultured $\mathrm{WB}$ as well as $\mathrm{WB}^{\mathrm{DC}(\text { Control)-MLC }}$, beside $\mathrm{NK}^{\mathrm{CD} 161+}$ cells showing no significant difference compared to uncultured WB and iNKT cells showing no significant difference compared to $\mathrm{WB}^{\mathrm{DC}(\text { Control)- }}$ MLC. The IFNy secretion induced with DC/DC $\mathrm{Deu}-$ Kit-I hereby emerged to be greater than with $\mathrm{DC} / \mathrm{DC}_{\mathrm{leu}}-\mathrm{Kit}-\mathrm{M}$. Noteworthy, the stimulation of IFNy secretion was independent from patients' age, sex, or blast frequency. Overall, we found an increased immunological activity of innate and adaptive immunoreactive cells after $\mathrm{DC} / \mathrm{DC}_{\mathrm{leu}}$ stimulation, pointing to an induction of leukaemia-specific cells.

Moreover, we compared frequencies of IFNy-secreting cells in uncultured WB and cultured $\mathrm{WB}^{\mathrm{DC}(\mathrm{Control})-\mathrm{MLC}}$ to assess the effect of cultivation on the secretion of IFNy. We could not find significant differences in anycelltypes, besides lower levels of IFNy-secreting $\mathrm{NK}^{\mathrm{CD} 161+}$ cells after cultivation. This might be due to an IL-2-induced expression of lectin-like transcript 1 (LLT1) on various cells, as cross-linking of LLT1 and CD161 on $\mathrm{NK}^{\mathrm{CD} 161+}$ cells results in an inhibition of IFNy production and cytotoxicity $[59,60]$. However, it seems that cells stimulated with DC/ $\mathrm{DC}_{\mathrm{leu}}$-Kit-I and -Kit-M can slightly compensate this effect. In regard to future clinical application, we suppose the effect of IL-2-induced $\mathrm{NK}^{\mathrm{CD} 161+}$ inhibition by LLT1 in vitro to be negligible in vivo, as IL-2 was supplemented. Overall, these findings show that no spontaneous activation of immunoreactive cells during DCC and MLC occurs.

We furthermore investigated the effect of LAA (WT-1 and PRAME) stimulation on $\mathrm{DC} / \mathrm{DC}_{\mathrm{leu}}$-stimulated adaptive immunoreactive cells. We hypothesised, that the addition of LAA can only increase the IFNy secretion of cells that have not been subject to LAA-dependent activation. Conformably, the addition of WT-1 and PRAME did (n.s.) increase frequencies of IFNy-secreting cells in uncultured $\mathrm{WB}$ and $\mathrm{WB}^{\mathrm{DC}(\text { Control)-MLC }}$. In contrast, the addition of LAA did not further increase frequencies of IFNysecreting cells in $\mathrm{WB}^{\mathrm{DC}(\mathrm{I})-\mathrm{MLC}}$ and $\mathrm{WB}^{\mathrm{DC}(\mathrm{M})-\mathrm{MLC}}$, affirming that these immunoreactive cells have been subject to activation through leukaemia-specific antigens presented by $\mathrm{DC}_{\text {leu }}-$ Kit-I and -Kit-M, in this case the known LAAs WT-1 and PRAME, whereby no further effect was possible. Remarkably, WT-1 and PRAME are only two of hundreds of leukaemic blast antigens presented by $\mathrm{DC}_{\text {leu, }}$, giving $\mathrm{DC}_{\text {leu }}$ the exceptional potential to initiate a comprehensive leukaemia-specific immune response.

\section{Correlation of IFNy-Positive Cells Obtained by CSA and ICA}

In order to validate frequencies of IFNy-producing immunoreactive cells obtained by CSA, we performed parallel ICAs and correlated the results. We found a significantly high correlation of obtained frequencies between both methods. Both the CSA and ICA yielded comparable frequencies of IFNy-positive $\mathrm{T}^{\mathrm{CD} 3+}, \mathrm{T}^{\mathrm{CD} 4+}, \mathrm{T}^{\mathrm{CD} 8+}$, $\mathrm{CIK}^{\mathrm{CD} 56+}, \mathrm{NK}^{\mathrm{CD} 56+}$, and iNKT cells.

\section{Correlation of IFNy Secretion and Anti-Leukaemic \\ Cytotoxicity of $D C / D C_{\text {leu }}$-Stimulated Immunoreactive Cells \\ We conclusively correlated the IFNy secretion with the} anti-leukaemic cytotoxicity in $\mathrm{WB}^{\mathrm{DC}(\mathrm{M})-\mathrm{MLC}}$ and found a significantly positive correlation between the IFNy secretion of $\mathrm{T}^{\mathrm{CD} 3+}, \mathrm{T}^{\mathrm{CD} 4+}, \mathrm{T}^{\mathrm{CD} 8+}$ as well as $\mathrm{NK}^{\mathrm{CD} 56+}$ cells and the 24-h anti-leukaemic cytotoxicity. Though the other immune cells ( $\mathrm{NK}^{\mathrm{CD} 161+}, \mathrm{CIK}^{\mathrm{CD} 56+}, \mathrm{CIK}^{\mathrm{CD} 161+}$ cells) did not show a direct correlation to cytotoxicity, they showed a (n.s.) increased secretion of IFNy pointing towards an increased activity, which may contribute indirectly to the overall leukaemia-specific activity. Ultimately, cytotoxicity remains dependent on the great interaction of various cells, 
cytokines, and other factors $[12,35]$. Nevertheless, IFNy can reflect the cytotoxic activity of $\mathrm{T}^{\mathrm{CD} 3+}, \mathrm{T}^{\mathrm{CD} 4+}, \mathrm{T}^{\mathrm{CD} 8+}$, and $\mathrm{NK}^{\mathrm{CD} 56+}$ cells. With this knowledge, we suppose that IFNy readouts of these specific cell groups are sufficient to assess and monitor the efficacy of AML immunotherapy.

\section{Evaluation of the CSA}

There are various techniques to investigate the cytokine production of immune cells on a single cell level, including the CSA, ICA, and Elispot technology. The central technique used in this study was the CSA, which allowed us to detect and phenotypically analyse IFNy-secreting immunoreactive cells on a single cell level and moreover display $\mathrm{DC} / \mathrm{DC}_{\mathrm{leu}}$-induced leukaemiaspecific activity and cytotoxicity. It hereby presented itself as a convenient, valid, and reliable method [61].

The ICA has, like the CSA, the potential to detect and phenotypical characterise IFNy-producing cells, however, potentially with a lower sensitivity than the CSA, especially when dealing with low frequencies of IFNy-positive cells [61-64]. Overall though, we and others found the IFNy production obtained by the CSA and ICA highly correlating [65]. Notably, the ICA holds the capacity to simultaneously analyse further cellular markers like $\mathrm{TNFa}$, but, contrary to the CSA, is more time consuming and inevitably kills analysed cells [66]. The Elispot technology, an enzyme-linked cytokine capture assay, enables the detection of IFNy-producing cells with a high sensitivity, but lacks their phenotypical characterisation if cells are not previously sorted into cellular subsets of interest [67]. Noteworthily, the CSA, contrary to the ICA and the Elispot, holds the potential to isolate viable IFNy-expressing cells, if the interest lies in expansion, further functional analyses (e.g., MHC/peptide-tetramer staining), or cell therapy (e.g., adoptive T-cell transfer) $[68,69]$.

With IFNy assays being able to display leukaemia-specific cells as well as anti-leukaemic cytotoxicity, they are in advantage of regular cytotoxicity assays. Assays like fluorochrome-labelled assays, 51CR-labelled assays, degranulation assays, and LDH assays only allow the evaluation of achieved cytotoxicity but lack the characterisation of overall participating (leukaemia-specific) cells [70-72]. However, they best depict functionally active Tc, as they directly measure the lysis of target cells [73]. Nonetheless, these assays are often very labour-intensive and unsuited for upscaling as needed in clinical applications. A more specific identification of Tc can only be accomplished by $\mathrm{MHC} /$ peptide-tetramer staining, yet this method requires a specific target antigen, in contrary to IFNy and cytotoxicity assays, and does not assure the functionality of the specific T-cell receptor [73, 74].

All in all, the CSA technology holds multiple advantages compared to other cytokine and cytotoxicity assays, especially by combining characterising and functional data.

\section{Conclusion}

We were able to describe the potential of $\mathrm{DC} / \mathrm{DC}_{\text {leu }}$ to induce or improve leukaemia-specific and anti-leukaemic activity through the detection of IFNy-secreting innate and adaptive immune cells ex vivo. The CSA in this regard proved to be a convenient and reproducible technique to detect and phenotypically characterise IFNy-secreting cells. As such, we believe that IFNy could become a very valuable parameter to assess and monitor the efficacy of AML immunotherapy in future clinical applications.

\section{Acknowledgement}

The authors thank patients, nurses, and physicians for their support with sample materials and diagnostic reports. The results presented in this article are part of the doctoral thesis of Lara Kristina Klauer at the University Hospital of the Ludwig Maximilian University Munich.

\section{Statement of Ethics}

Sample collection was conducted after obtaining written informed consent of the blood donor and in accordance with the World Medical Association Declaration of Helsinki and the ethic committee of the Ludwig Maximilian University Hospital Munich (vote No. 33905).

\section{Conflict of Interest Statement}

Modiblast Pharma GmbH (Oberhaching, Germany) holds the European Patent 15801 987.7-1118 and US Patent 15-517627 "Use of immunomodulatory effective compositions for the immunotherapeutic treatment of patients suffering from myeloid leukemias", in which H.M.S. is involved.

\section{Author Contributions}

L.K.K conducted DCC, MLC, CTX, and CSA experiments and all flow cytometric and statistical analyses. O.S., S.U., F.D.-G., and N.R. performed additional DCC, MLC, CTX, and CSA experiments, which were analysed by L.K.K. O.S. conducted ICA experiments, which were analysed by L.K.K. D.K., A.R., and C.S. provided leukaemic whole blood samples and corresponding diagnostic reports. D.C.A. and B.E.-V. supported functionality assays. H.M.S. designed the study. L.K.K and H.M.S. drafted the manuscript.

\footnotetext{
References $\quad 1$ Sawyers CL, Denny CT, Witte ON. Leukemia and the disruption of normal hematopoiesis. Cell. 1991;64(2):337-50.

2 Smith M, Barnett M, Bassan R, Gatta G, Tondini C, Kern W. Adult acute myeloid leukaemia. Crit Rev Oncol Hematol. 2004;50(3): 197-222.

3 Döhner H, Estey E, Grimwade D, Amadori S, Appelbaum FR, Büchner T, et al. Diagnosis and management of AML in adults: 2017 ELN recommendations from an international expert panel. Blood. 2017;129(4):424-47.
} 
4 Short NJ, Rytting ME, Cortes JE. Acute myeloid leukaemia. Lancet. 2018;392(10147): 593-606.

5 Deschler B, Lübbert M. Acute myeloid leukemia: epidemiology and etiology. Acute Leukemias. Springer; 2008. p. 47-56.

6 Hokland P, Woll PS, Hansen MC, Bill M. The concept of leukaemic stem cells in acute myeloid leukaemia 25 years on: hitting a moving target. Br J Haematol. 2019 Oct;187(2):14456.

7 National Cancer Institute. Cancer Stat Facts: Leukaemia - Acute Myeloid Leukaemia (AML) [Internet]. 2020 [cited 11 February 2020]. Available from: https://seer.cancer. gov/statfacts/html/amyl.html.

8 Pyzer AR, Avigan DE, Rosenblatt J. Clinical trials of dendritic cell-based cancer vaccines in hematologic malignancies. Hum Vaccin Immunother. 2014;10(11):3125-31.

9 Constantino J, Gomes C, Falcão A, Neves BM, Cruz MT. Dendritic cell-based immunotherapy: a basic review and recent advances. Immunol Res. 2017;65(4):798-810.

10 Lichtenegger FS, Krupka C, Haubner S, Köhnke T, Subklewe M. Recent developments in immunotherapy of acute myeloid leukemia. J Hematol Oncol. 2017;10(1):142.

11 Ansprenger C, Amberger DC, Schmetzer HM. Potential of immunotherapies in the mediation of antileukemic responses for patients with acute myeloid leukemia (AML) and myelodysplastic syndrome (MDS)-With a focus on Dendritic cells of leukemic origin (DCleu) Clinical Immunology. 2020.108467.

12 Chaplin DD. Overview of the immune response. Journal of Allergy and Clinical Immunology. 2010;125(2):S3-S23.

13 Mellman I. Dendritic cells: master regulators of the immune response. Cancer Immunol Res. 2013;1(3):145-9.

14 Narita M, Takahashi M, Liu A, Ayres F, Satoh $\mathrm{N}$, Abe T, et al. Generation of dendritic cells from leukaemia cells of a patient with acute promyelocytic leukaemia by culture with GM-CSF, IL-4 and TNF-alpha. Acta Haematol. 2001;106(3):89-94.

15 Cignetti A, Vallario A, Roato I, Circosta P, Allione B, Casorzo L, et al. Leukemia-derived immature dendritic cells differentiate into functionally competent mature dendritic cells that efficiently stimulate $\mathrm{T}$ cell responses. Immunol. 2004;173(4):2855-65.

16 Kremser A, Dressig J, Grabrucker C, Liepert A, Kroell T, Scholl N, et al. Dendritic cells (DCs) can be successfully generated from leukemic blasts in individual patients with AML or MDS: an evaluation of different methods. J Immunother. 2010;33(2):18599.

17 Schmetzer HM, Kremser A, Loibl J, Kroell T, Kolb HJ. Quantification of ex vivo generated dendritic cells (DC) and leukemia-derived DC contributes to estimate the quality of DC, to detect optimal DC-generating methods or to optimize DC-mediated T-cell-activationprocedures ex vivo or in vivo. Leukemia. 2007;21(6):1338-41.

18 Grabrucker C, Liepert A, Dreyig J, Kremser A, Kroell T, Freudenreich M, et al. The quality and quantity of leukemia-derived dendritic cells from patients with acute myeloid leuke- mia and myelodysplastic syndrome are a predictive factor for the lytic potential of dendritic cells-primed leukemia-specific T cells. J Im munother. 2010;33(5):523-37.

19 Liepert A, Grabrucker C, Kremser A, Dreyssig J, Ansprenger C, Freudenreich M, et al. Quality of T-cells after stimulation with leukemiaderived dendritic cells (DC) from patients with acute myeloid leukemia (AML) or myeloid dysplastic syndrome (MDS) is predictive for their leukemia cytotoxic potential. Cell Immunol. 2010;265(1):23-30.

20 Boeck CL, Amberger DC, Doraneh-Gard F, Sutanto W, Guenther T, Schmohl J, et al. Significance of frequencies, compositions, and/ or antileukemic activity of (DC-stimulated) invariant NKT, NK and CIK cells on the outcome of patients with AML, ALL and CLL. J Immunother. 2017;40(6):224-48.

21 Lowin B, Hahne M, Mattmann C, Tschopp J. Cytolytic T-cell cytotoxicity is mediated through perforin and Fas lytic pathways. $\mathrm{Na}$ ture. 1994;370(6491):650-2.

22 Hassin D, Garber OG, Meiraz A, Schiffenbauer YS, Berke G. Cytotoxic T lymphocyte perforin and Fas ligand working in concert even when Fas ligand lytic action is still not detectable. Immunology. 2011;133(2):190-6.

23 Martinez-Lostao L, de Miguel D, Al-Wasaby S, Gallego-Lleyda A, Anel A. Death ligands and granulysin: mechanisms of tumor cell death induction and therapeutic opportunities. Immunotherapy. 2015;7(8):883-2.

24 Ikeda H, Old LJ, Schreiber RD. The roles of IFN gamma in protection against tumor development and cancer immunoediting. Cytokine Growth Factor Rev. 2002;13(2):95-109.

25 Kursunel MA, Esendagli G. Corrigendum to "The untold story of IFN- $\gamma$ in cancer biology" [Cytokine Growth Factor Rev. 31 (2016) 7381]. Cytokine Growth Factor Rev. 2017 2017/06;35(97).

26 Castro F, Cardoso AP, Gonçalves RM, Serre $\mathrm{K}$, Oliveira MJ. Interferon-Gamma at the Crossroads of Tumor Immune Surveillance or Evasion. Front Immunol. 2018 2018/05/04; 9:847.

27 Schroder K, Hertzog PJ, Ravasi T, Hume DA. Interferon- $\gamma$ : an overview of signals, mechanisms and functions. Journal of Leukocyte Biology. 2003 2003/10/02;75(2):163-89.

28 Schoenborn JR, Wilson CB. Regulation of Interferon- $\gamma$ During Innate and Adaptive Immune Responses. Advances in Immunology. Elsevier; 2007. p. 41-101.

$29 \mathrm{Xu}$ X, Fu XY, Plate J, Chong AS. IFN-gamma induces cell growth inhibition by Fas-mediated apoptosis: requirement of STAT1 protein for up-regulation of Fas and FasL expression. Cancer Res. 1998 Jul 1;58(13):2832-7.

30 Detjen KM, Farwig K, Welzel M, Wiedenmann B, Rosewicz S. Interferon gamma inhibits growth of human pancreatic carcinoma cells via caspase- 1 dependent induction of apoptosis. Gut. 2001 2001/08/01;49(2):251-62.

31 Ruiz-Ruiz C, LÓPez-Rivas A. Mitochondriadependent and -independent mechanisms in tumour necrosis factor-related apoptosis-inducing ligand (TRAIL)-induced apoptosis are both regulated by interferon- $\gamma$ in human breast tumour cells. Biochemical Journal. 2002 2002/08/01;365(3):825-32.
32 Pizzoferrato E, Liu Y, Gambotto A, Armstrong MJ, Stang MT, Gooding WE, et al. Ectopic Expression of Interferon Regulatory Factor-1 Promotes Human Breast Cancer Cell Death and Results in Reduced Expression of Survivin. Cancer Res. 2004 2004/11/15; 64(22):8381-8

33 Ruiz-Ruiz C, Ruiz de Almodóvar C, Rodríguez A, Ortiz-Ferrón G, Redondo JM, LópezRivas A. The Up-regulation of Human Caspase- 8 by Interferon- $\gamma$ in Breast Tumor Cells Requires the Induction and Action of the Transcription Factor Interferon Regulatory Factor-1. Journal of Biological Chemistry. 2004 2004/03/01;279(19):19712-20.

34 Kaiko GE, Horvat JC, Beagley KW, Hansbro PM. Immunological decision-making: how does the immune system decide to mount a helper T-cell response?. Immunology. 2008 2008/03;123(3):326-38

35 Bonilla FA, Oettgen HC. Adaptive immunity. J Allergy Clin Immunol. 2010 2010/02;125(2): S33-40.

36 Young HA, Hardy KJ. Role of interferongamma in immune cell regulation. J Leukoc Biol. 1995 1995/10;58(4):373-81.

37 Shtrichman R, Samuel CE. The role of gamma interferon in antimicrobial immunity. Curr Opin Microbiol. 2001 2001/06;4(3):251-9.

38 Amberger DC, Doraneh-Gard F, Gunsilius C, Weinmann M, Möbius S, Kugler C, et al. PGE1-Containing Protocols Generate Mature (Leukemia-Derived) Dendritic Cells Directly from Leukemic Whole Blood. Int J Mol Sci. 2019 2019/09/17;20(18):4590.

39 Plett CA, Christoph D, Rabe A, Deen D, Stankova Z, Hirn A, et al. Kits do not induce AML-blasts' proliferation ex vivo. IPO-38 is an appropriate and reliable marker to detect and quantify proliferating blasts. Eur J Cancer. 2017;5(1):3-4.

40 Doraneh gard F, Amberger D, Weinmann M, Boeck C, Gunsilius C, Kugler C, et al. Standard normoxic versus physiological hypoxic culture of AML patients' (pts) whole blood (WB) samples with immune modulatory kits yields comparable proportions of dendritic cells and functional results. European Journal of Cancer. 2018 2018/03;92:S10-1.

41 Vogt V, Schick J, Ansprenger C, Braeu M, Kroell T, Kraemer D, et al. Profiles of activation, differentiation-markers, or $\beta$-integrins on T cells contribute to predict T cells' antileukemic responses after stimulation with leukemia-derived dendritic cells. J Immunother. 2014;37(6):331-47.

42 Geiger TL, Rubnitz JE. New approaches for the immunotherapy of acute myeloid leukemia. Discov Med. 2015 Apr;19(105):275-84.

43 Holzinger A, Barden M, Abken $\mathrm{H}$. The growing world of CAR T cell trials: a systematic review. Cancer Immunol Immunother. Immunotherapy2016 2016/09/09;65(12):1433-50.

44 Biernacki MA, Brault M, Bleakley M. T-Cell Receptor-Based Immunotherapy for Hematologic Malignancies. Cancer J. 2019;25(3): 179-90.

45 Anguille S, Van Tendeloo VF, Berneman ZN. Leukemia-associated antigens and their relevance to the immunotherapy of acute myeloid leukemia. Leukemia. 2012 2012/06/01;26(10): 2186-96. 
46 Goswami M, Hensel N, Smith BD, Prince GT, Qin L, Levitsky HI, et al. Expression of putative targets of immunotherapy in acute myeloid leukemia and healthy tissues. Leukemia. 2014 2014/01/10;28(5):1167-70.

47 Li L, Giannopoulos K, Reinhardt P, Tabarkiewicz J, Schmitt A, Greiner J, et al. Immunotherapy for patients with acute myeloid leukemia using autologous dendritic cells generated from leukemic blasts. Int J Oncol. 2006 Apr;28(4):855-61.

48 Roddie H, Klammer M, Thomas C, Thomson R, Atkinson A, Sproul A, et al. Phase I/II study of vaccination with dendritic-like leukaemia cells for the immunotherapy of acute myeloid leukaemia. Br J Haematol. 2006 Apr;133(2): 152-7.

49 Anguille S, Lion E, Smits E, Berneman ZN, van Tendeloo VF. Dendritic cell vaccine therapy for acute myeloid leukemia: Questions and answers. Hum Vaccin. 2011 2011/05; 7(5):579-84

50 Dong M, Liang D, Li Y, Kong D, Kang P, Li K, et al. Autologous dendritic cells combined with cytokine-induced killer cells synergize low-dose chemotherapy in elderly patients with acute myeloid leukaemia. J Int Med Res. 2012;40(4):1265-74.

51 Amberger DC, Schmetzer HM. Dendritic Cells of Leukemic Origin: Specialized Antigen-Presenting Cells as Potential Treatment Tools for Patients with Myeloid Leukemia. Transfusion Medicine and Hemotherapy. 2020.

52 Eiz-Vesper B, Schmetzer HM. Antigen-Presenting Cells: Potential of Proven und New Players in Immune Therapies. Transfusion Medicine and Hemotherapy. 2020.

53 Ogihara T, Iinuma H, Okinaga K. Usefulness of immunomodulators for maturation of dendritic cells. International Journal of Oncology. 2004 2004/08/01.

54 Förster R, Davalos-Misslitz AC, Rot A. CCR7 and its ligands: balancing immunity and tolerance. Nat Rev Immunol. 2008 2008/05;8(5): 362-71.

55 Platt AM, Randolph GJ. Dendritic Cell Migration Through the Lymphatic Vasculature to Lymph Nodes. Development and Function of Myeloid Subsets. Elsevier; 2013. p. 51-68.
56 Boyman O, Sprent J. The role of interleukin-2 during homeostasis and activation of the immune system. Nat Rev Immunol. 2012 2012/02/17;12(3):180-90.

57 Osada T, Clay T, Hobeika A, Lyerly HK, Morse MA. NK cell activation by dendritic cell vaccine: a mechanism of action for clinical activity. Cancer Immunol ImmunotherImmunotherapy. 2005 2005/11/05;55(9): $1122-31$.

58 Introna $\mathrm{M}$, Correnti $\mathrm{F}$. Innovative Clinical Perspectives for CIK Cells in Cancer Patients. Int J Mol Sci. 2018 2018/01/25;19(2):358.

59 Aldemir H, Prod'homme V, Dumaurier MJ, Retiere C, Poupon G, Cazareth J, et al. Cutting Edge: Lectin-Like Transcript 1 Is a Ligand for the CD161 Receptor. J Immunol. 2005 2005/12/08;175(12):7791-5

60 Llibre A, Klenerman P, Willberg CB. Multifunctional lectin-like transcript-1: A new player in human immune regulation. Immunol Lett. 2016 2016/09;177:62-9.

61 Desombere I, Meuleman P, Rigole H, Willems A, Irsch J, Leroux-Roels G. The interferon gamma secretion assay: a reliable tool to study interferon gamma production at the single cell level. J Immunol Methods. 2004 2004/03;286(1-2):167-85.

62 Nomura LE, Walker JM, Maecker HT. Optimization of whole blood antigen-specific cytokine assays for CD4(+) T cells. Cytometry. 2000 2000/05/01;40(1):60-8.

63 Koehne G, Smith KM, Ferguson TL, Williams RY, Heller G, Pamer EG, et al. Quantitation, selection, and functional characterization of Epstein-Barr virus-specific and alloreactive $\mathrm{T}$ cells detected by intracellular interferon-gamma production and growth of cytotoxic precursors. Blood. 2002 2002/03/01;99(5):173040.

64 Jaimes MC, Maecker HT, Yan M, Maino VC, Hanley MB, Greer A, et al. Quality assurance of intracellular cytokine staining assays: Analysis of multiple rounds of proficiency testing. I Immunol Methods. 2011 2011/01;363(2): 143-57.

65 Oelke M, Kurokawa T, Hentrich I, Behringer D, Cerundolo V, Lindemann A, et al. Functional Characterization of CD8+ AntigenSpecific Cytotoxic T Lymphocytes after Enrichment Based on Cytokine Secretion: Comparison with the MHC-Tetramer Technology. Scandinavian Journal of Immunology. 2000 2000/12;52(6):544-9.
66 Mair F, Tosevski V. Intracellular Staining for Cytokines and Transcription Factors. Methods in Molecular Biology. New York: Springer; 2014. p. 39-49.

67 Calarota SA, Baldanti F. Enumeration and Characterization of Human Memory T Cells by Enzyme-Linked Immunospot Assays. Clinical and Developmental Immunology. 2013;2013:1-8.

68 Oelke M, Moehrle U, Chen JL, Behringer D, Cerundolo V, Lindemann A, et al. Generation and purification of CD8+ melan-A-specific cytotoxic T lymphocytes for adoptive transfer in tumor immunotherapy. Clin Cancer Res. 2000 May;6(5):1997-2005.

69 Van Rhijn I, Iwany SK, Fodran P, Cheng TY, Gapin L, Minnaard AJ, et al. CD1b-mycolic acid tetramers demonstrate T-cell fine specificity for mycobacterial lipid tails. Eur J Immunol. 2017 2017/07/31;47(9):1525-34.

70 Kienzle N, Olver S, Buttigieg K, Kelso A. The fluorolysis assay, a highly sensitive method for measuring the cytolytic activity of T cells at very low numbers. J Immunol Methods. 2002 2002/09;267(2):99-108.

71 Lorenzo-Herrero S, Sordo-Bahamonde C, Gonzalez S, López-Soto A. CD107a Degranulation Assay to Evaluate Immune Cell Antitumor Activity. Methods in Molecular Biology. New York: Springer; 2018. p. 119-30.

72 Lemonnier FA. Evaluating CD8+ T Cell Responses In VitroAntigen Processing. New York: Springer; 2019. p. 199-215.

73 Michel N, Öhlschläger P, Osen W, Freyschmidt E-J, Guthöhrlein H, Kaufmann AM, et al. T Cell Response to Human Papillomavirus 16 E7 in Mice: Comparison of $\mathrm{Cr}$ Release Assay, Intracellular IFN- $\gamma$ Production, ELISPOT and Tetramer Staining. Intervirology. 2002;45(4-6):290-9.

74 Dolton G, Tungatt K, Lloyd A, Bianchi V, Theaker SM, Trimby A, et al. More tricks with tetramers: a practical guide to staining $\mathrm{T}$ cells with peptide-MHC multimers. Immunology. 2015 2015/08/04;146(1):11-22

75 Schick J, Vogt V, Zerwes M, Kroell T, Kraemer D, Köhne CH, et al. Antileukemic T-cell Responses Can Be Predicted by the Composition of Specific Regulatory T-cell Subpopulations. J Immunother. 2013 2013/05;36(4): 223-37. 